\title{
Agnieszka Szczepaniak-Kroll
}

agnieszka.szczepaniak.kroll@gmail.com

Instytut Archeologii i Etnologii PAN

ORCID: 0000-0002-6577-8425

\section{ROLA LIDERÓW W KSZTALTOWANIU I PROMOWANIU DZIEDZICTWA KULTUROWEGO POZNAŃSKICH BAMBRÓW}

\section{The role of leaders in shaping and promoting the cultural heritage of the Posnanian Bambers}

Streszczenie: Rok 1989 był pod wieloma względami datą przełomową w najnowszej historii Polski. Zmiana systemu politycznego z socjalistycznego na kapitalistyczny, zainicjowana w tym okresie, uwolniła wiele procesów związanych z etnicznością. Również „renesans” poznańskich Bambrów okazał się bezpośrednim skutkiem transformacji ustrojowej. Potomkowie osadników, przybyłych do Poznania w 1719 r., w czasie swego ponad 300-letniego zamieszkiwania w podpoznańskich wsiach niejednokrotnie zagrożeni byli asymilacją. Wypracowali więc swoje strategie zachowania tożsamości, które stosowali również przed $1989 \mathrm{r}$. Były one indywidualne, przez nikogo niekoordynowane. W latach 90 . XX w. po raz pierwszy w ich historii pojawili się liderzy, przywódcy kulturowi, którzy zaopiekowali się dziedzictwem Bambrów jako grupy, przystąpili do jego zbadania, utrwalenia i spopularyzowania. $\mathrm{W}$ artykule jest mowa o dwóch osobach - Marii Paradowskiej i Ryszardzie Skibińskim, mających na tym polu szczególne osiągnięcia. Takie osoby - aktorzy społeczni (nazywani dziś coraz częściej interesariuszami), mają znaczący wpływ na kształt dziedzictwa kulturowego grupy, dla której działają, i na sposób jego promowania. Artykuł opieram na wieloletniej obserwacji uczestniczącej i licznych rozmowach z bamberskimi liderami.

Słowa kluczowe: dziedzictwo kulturowe, Bambrzy, Poznań, liderzy, interesariusze 
Abstract: The year 1989 was a breakthrough date in Poland's recent history in various aspects. The change of the political system from socialist to capitalist, initiated in this period, freed many processes related to ethnicity. Also, the "renaissance" of Posnanian Bambers proved to be a direct result of the political transformation. Descendants of settlers who came to Poznan in 1719, during their more than 300 years of living in villages near Poznań, were often threatened with assimilation. So they developed their strategies of identity preservation, which they also used before 1989. Those strategies were individual, uncoordinated by anyone. In the 1990s, cultural leaders appeared for the first time in their history and took care of the heritage of the Bambers as a group. They began to search, popularize this cultural heritage and consolidate the group. The article mentions two people - Maria Paradowska and Ryszard Skibiński, who have special achievements in this field. Such people - social actors (today more often called stakeholders) have a significant impact on the shape of the cultural heritage of the group for which they operate and on the way it is promoted. I base the article on many years of participant observation and numerous conversations with Bamber leaders.

Key words: cultural heritage, Bambers, Poznan, leaders, stakeholders

\section{Wprowadzenie}

Rok 1989 był pod wieloma względami datą przełomową w najnowszej historii Polski. Zmiana systemu politycznego z socjalistycznego na kapitalistyczny, zainicjowana $\mathrm{w}$ tym okresie, uwolniła wiele procesów związanych z etnicznością, zwłaszcza z jej aspektami, które dotąd musiały pozostać $\mathrm{w}$ uśpieniu $\mathrm{z}$ uwagi na obowiązującą ideę jednego, homogenicznego narodu. Mniejszości narodowe, etniczne, językowe i kulturowe w nowej rzeczywistości, na przestrzeni kilku lat, zostały dostrzeżone, docenione i objęte różnymi formami ochrony. Również „renesans” poznańskich Bambrów okazał się bezpośrednim skutkiem transformacji ustrojowej. Potomkowie osadników przybyłych do Poznania w $1719 \mathrm{r}$. w czasie swego ponad 300-letniego zamieszkiwania w podpoznańskich wsiach (włączonych na przełomie XIX i XX w. w obręb miasta) niejednokrotnie zagrożeni byli asymilacją, co zmuszało ich do wypracowania 
Rola liderów w kształtowaniu i promowaniu dziedzictwa...

skutecznych strategii służących przetrwaniu dziedzictwa kulturowego i zachowaniu tożsamości. Okres po II wojnie światowej należał do tych trudnych momentów. Jednak i tym razem skuteczne okazały się działania tej grupy, mające na celu podtrzymanie pamięci o korzeniach, mimo iż były podejmowane intuicyjnie, w sferze prywatnej, rodzinnej, w sposób odgórnie niekoordynowany, niezaplanowany.

W latach 90. XX w. po raz pierwszy w jej historii pojawili się liderzy, przywódcy kulturowi, którzy odświeżyli nieco zapomnianą przez otoczenie historię osadników, doprowadzili do zorganizowania Bambrów we własne stowarzyszenie, zapewnili im stałą siedzibę, powołali muzeum. Przywrócili oni bamberskie dziedzictwo kulturowe w świadomości poznaniaków, pogłębili wiedzę o nim i sprawili, że zostało docenione jako ważny element regionalnej kultury, tożsamości Poznania i jego pobliskich okolic. Ich działania ewoluowały, wpasowując się w dynamicznie zmieniające się realia i potrzeby człowieka, wśród których jedno z podstawowych miejsc zajmuje więź z najbliższym otoczeniem, doskonale wyrażonym w niemieckim określaniu Heimat, niemającym niestety adekwatnego polskiego odpowiednika.

To właśnie aktywności tych osób chciałabym poświęcić artykuł. Opieram się w nim na wieloletnich badaniach jakościowych prowadzonych wśród Bambrów ${ }^{1}$, obserwacji uczestniczącej, osobistych wspomnieniach związanych z twórczynią ich fenomenu prof. dr hab. Marią Paradowską - jednocześnie moją wieloletnią kierowniczką w Instytucie Archeologii i Etnologii PAN, oraz na wywiadzie-rzece z obecnym liderem owej aktywności Ryszardem Skibińskim (z 2020 roku) i innych, kilkakrotnie w ostatnich latach prowadzonych przez nas rozmowach. Środowisko poznańskich Bambrów jest mi bardzo dobrze znane. Przez wiele lat, począwszy od 2000 r., prowadząc badania, wspierałam tę gru-

${ }^{1}$ Takie badania prowadziłam w latach 2000-2009 w Poznaniu i w latach 2000-2005 w Niemczech, w Bambergu. Dotyczyły one tożsamości poznańskich Bambrów i ich wkładu w dziedzictwo kulturowe Poznania. W Poznaniu skoncentrowałam się głównie na wywiadach z potomkami Bambrów, stosując techniki wywiadu swobodnego i rodzinnego. Prowadziłam także prace poszukiwawcze w Archiwum Państwowym i w Archiwum Archidiecezjalnym. Ich celem było skompletowanie wszystkich dostępnych materiałów dotyczących Bambrów, obejmujących okres od momentu przybycia do Poznania do wieku XX (metoda dokumentów osobistych). Prace prowadzone w Niemczech obejmowały wywiady z mieszkańcami miasta, wywiady eksperckie, lecz głównie ogniskowały się na pracy nad materiałami zastanymi, zgromadzonymi w trzech niemieckich archiwach: Stadtarchiv, Staatsarchiv i w Archiv des Erzbistums Bamberg. 
pę w licznych podejmowanych przez nią działaniach, pomagałam m.in. w tłumaczeniu dokumentów i listów z i do Bambergu, w czasie wizyt delegacji z Niemiec czy przy obsłudze spotkań zarządu. Towarzyszyłam im podczas różnego rodzaju imprez, takich jak Jarmark Świętojański, Warkocz św. Magdaleny i Noc Muzeów, w procesjach Bożego Ciała, corocznie obchodzonym święcie bamberskim, w różnego rodzaju spotkaniach z władzami Poznania i Bambergu, przy promocjach książek, w mniej lub bardziej oficjalnych przyjęciach i wyjazdach - także poza miasto, w tym do Bambergu. Byłam zapraszana przez zarząd Towarzystwa Bambrów Poznańskich (dalej TBP) do wygłoszenia prelekcji na temat historii i kultury tej grupy na walnych zebraniach. Wzięłam także udział w większości imprez z okazji obchodzonego w 2019 r. jubileuszu 300-lecia przybycia Bambrów do Poznania. Mimo wielu zachęt nigdy nie zapisałam się jednak do TBP, obawiając się, że mogłoby to zmniejszyć mój obiektywizm w stosunku do badanej materii. Takie stanowisko pozwoliło mi wcielić się w rolę „uczestnika-jako-obserwatora” (Angrosino 2020: 108), który integruje się z życiem badanej grupy, stara się być w równym stopniu badaczem co przyjacielem, lecz przy zachowaniu odpowiedniego dystansu. Dzięki temu moje działania podejmowane w calach badawczych były akceptowane i respektowane. Nigdy nie odnosiłam wrażenia, by w zarządzie cokolwiek starano się przede mną ukryć lub upiększyć. Mam więc poczucie, że udało mi się dobrze poznać liderów w działaniu, zrozumieć ich motywacje i styl działania.

\section{Kim są poznańscy Bambrzy?}

Poznański wątek dziejów Bambrów rozpoczął się na początku XVIII wieku. Wówczas katoliccy osadnicy z Górnej Frankonii, a dokładniej z kilku miejscowości położonych w promieniu około $60 \mathrm{~km}$ od Bambergu, przybyli do Poznania i otaczających go wsi: Dębca, Wildy, Rataj, Jeżyc, Bonina, Winiar, Górczyna, Lubonia, a także do położonych nieco dalej Czapur i Wiórka. Ich zadaniem była odbudowa tutejszej gospodarki po wojnach toczących się w XVII stuleciu, po klęskach żywiołowych i zarazie. Pierwsza grupa osiedliła się na obrzeżach miasta (w Luboniu) w 1719 r., w jej ślady przez ponad 50 kolejnych lat podążały kolejne. Byli to przede wszystkim ludzie trudniący się uprawą ziemi, często najubożsi mieszkańcy regionu pochodzenia. Do wyjazdu, jak w przypadku większości migra- 
cji, skłaniała ich bieda i brak perspektyw. W Poznaniu wymagano jedynie, by byli katolikami i znali się na pracy na roli, co miało zagwarantować osiągnięcie wyznaczonych przez miasto celów, do których należało odbudowanie przedmieść, stanowiących zaplecze żywnościowe Poznania, i zintegrowanie przybyszów z polskimi chłopami. Bamberczycy i ich potomkowie nadspodziewanie dobrze odnaleźli się w poznańskich realiach. Świadomi swej sytuacji, w tym niemożliwości powrotów, których im w ojczyźnie zabroniono, pieczołowicie wykonywali powierzone im obowiązki. Już pod koniec XVIII w. wyróżniali się zamożnością, osiągniętą dzięki zapewnionym przez magistrat korzystnym warunkom osadniczym: oczynszowaniu, pomocy materialnej w codziennym funkcjonowaniu i w zagospodarowaniu ziemi. Otrzymali m.in. pieniądze na podstawowe potrzeby, drewno do budowy domów i budynków gospodarczych oraz na opał, ziemię wielkości 0,5-1 huby², długie okresy wolnizn, czyli zwolnienia od płacenia podatków, ziarno na zasiew i do wypieku chleba, łąki i pastwiska w darmowe użytkowanie ${ }^{3}$.

Przez pewien czas starali się kontynuować przyniesione ze swoich wsi zwyczaje: modlili się z książeczek do nabożeństwa przywiezionych z Frankonii, kontynuowali obchody niektórych świąt (procesje ku czci św. Rocha i Urbana) $)^{4}$, budowali domy w sposób znany we Frankonii's. W końcu jednak nawet $\mathrm{w}$ ich pamięci zatarło się wyraźne rozgraniczenie tego, co ,autentycznie bamberskie” i tego, co nazwane zostało bamberskim w czasie długotrwałego zamieszkiwania grupy w Poznaniu i okolicach. Nie zmieniła się jednak tożsamość potomków imigrantów. W XIX w. słowo bamber (pisane małą literą w odróżnieniu od Bambrów - potomków osadników z Bambergu) stało się synonimem bogatego gospodarza z podpoznańskiej wsi. Wizerunek ten utrwalał strój bamberski, zwłaszcza kobiecy (męski zanikł z czasem), pełen przepychu widomy znak bogactwa ${ }^{6}$. Bambrów niezmiennie wiązano $\mathrm{z}$ niemieckim pochodzeniem, choć oni sami w momencie przybycia do Poznania i w kolejnych latach raczej nie określali się w kategoriach narodowych, identyfikując się przede wszystkim ze swoim najbliższym otoczeniem i co najwyżej regionem pochodzenia. Podczas zaborów uważani byli przez Polaków za „swoich obcych”.

\footnotetext{
${ }^{2} 1$ huba to 13,4 ha.

${ }^{3} \mathrm{Na}$ temat warunków osadnictwa Bambrów szerzej m.in. w książkach M. Paradowskiej (1998) oraz A. Szczepaniak-Kroll (2010).

${ }^{4} \mathrm{Na}$ ten temat pisała A. Szymoszyn (2019).

${ }^{5} \mathrm{O}$ budownictwie Bambrów pisała D. Leśniewska (2019).

${ }^{6} \mathrm{Na}$ temat stroju bamberskiego wyczerpująco pisała J. Minksztym (2015).
} 
W XIX w. wżenili się w polskie rodziny, zintegrowali z sąsiadami, którzy od dawna darzyli ich szacunkiem i przez pokolenia wybierali na zaszczytne na wsi stanowiska sołtysów i ławników. Co najważniejsze, Bambrów różniła od pruskich zaborców - protestantów - religia katolicka. Do końca XIX w. nie angażowali się w wielką politykę. Pozostawali chłopami, którzy byli zbyt zajęci codziennymi sprawami, by zastanawiać się nad tak wysublimowanymi sprawami jak tożsamość narodowa. Życie wypełniały im praca i religia. Dopiero wynaradawiająca polityka Ottona von Bismarcka pod koniec XIX w., znajdująca odbicie w codziennym życiu poznaniaków (kwestia Kulturkampfu silnie przejawiająca się w Kościele, a także dotykająca szkół, urzędów, kolei itd.), zmusiła ich do wyboru narodowości. Kierując się „po wiejsku” podobieństwem do sąsiadów i licznych polskich członków swoich rodzin, jak również wobec obcości kulturowej Prusaków, uznali się za Polaków, choć ze źródeł historycznych wiemy, że nie przyszło im to z łatwością (Bär 1882: 35-46; Trzeciakowski 1970: 192).

Na przełomie XIX i XX w. większość wsi bamberskich zaczęto włączać w obręb Poznania. Zagrożony został ważny element kultury Bambrów - profesja rolnicza, stanowiąca jednocześnie jeden z filarów ich tożsamości. Potomkowie osadników z trudem odnajdowali się w nowych realiach. Zmieniali status społeczny, stając się mieszczanami (z czym ostatecznie bardzo dobrze sobie poradzili) stosunkowo krótko po tym, jak stali się Polakami. Słowo bamber zyskało w tym czasie negatywny wydźwięk, zaczęto nim określać osoby nienadążające za modą, zacofane. Nie zdołało ono jednak zdominować dawnego obrazu Bambrów - zamożnych i pracowitych przybyszów z terenu dzisiejszych Niemiec.

Ich polonizacja nie pozostawiała już wówczas wątpliwości, z mniejszości etnicznej przemienili się w grupę etnokulturową. W czasie I wojny światowej jako Polacy, podobnie jak wielu mieszkańców zaboru pruskiego, służyli w niemieckim wojsku. Z kolei w czasie II wojny światowej z powodu korzeni skłaniano ich do podpisywania volkslisty (Deutsche Volksliste). Na ogół odmawiali, za co ponosili surowe konsekwencje, łącznie z karą śmierci. Zachowywali natomiast nadal swoje dziedzictwo kulturowe. W każdej dzielnicy miasta, utworzonej z bamberskich wsi, przez cały XX w. z łatwością wskazywano, która z mieszkających tam rodzin jest bamberska. Nadal kultywowano w nich bowiem pamięć o przodkach w oparciu o pamiątki rodzinne, fotografie, zachowane części stroju, ruchomości i nieruchomości, przekazywane historie rodzinne, tradycje 
związane z obrzędowością doroczną i rodzinną, tworzące ich dziedzictwo kulturowe. Dla Bambrów istotny był etos, który stał się częścią etosu poznaniaka, oparty na takich cechach jak pracowitość, gospodarność, oszczędność. Także charakterystyczną cechą pozostało ich skupianie się wokół Kościoła, jako nie tylko instytucji religijnej, ale i drugiego ważnego filaru tożsamości.

Tych elementów kultury nie był w stanie zniszczyć komunizm, który konsekwentnie budował wizerunek jednego etnicznie narodu. Mniejszości przedstawiano $\mathrm{w}$ nim jako relikt przedsocjalistycznych i historycznych czasów. Miały zniknąć wraz z wykształceniem się bezklasowego, socjalistycznego społeczeństwa. Eliminowano je z dyskursu publicznego. Edukacja szkolna nie podejmowała tematu ich obecności, wkładu w polskie kulturowe dziedzictwo czy w rozwój gospodarczy. Wykluczona była polityczna reprezentacja i jakakolwiek demonstracja tożsamości mniejszości (Mach 2010: 158-149).

\section{Renesans Bambrów w kulturze Poznania u schyłku XX w. i jego twór- czyni - Maria Paradowska}

W latach 90. XX w., w warunkach przemian ustrojowych, polskie władze odstąpiły od polityki asymilacyjnej na rzecz upodmiotowienia mniejszości, przede wszystkim narodowych i etnicznych, a one, mimo wyraźnego przystosowania się do otaczającej rzeczywistości, zaktywizowały swoje działania na rzecz zachowania odrębności kulturowej, ujawniając różnorodne związane z tym potrzeby. Państwo podjęło próbę zdefiniowania tych grup, określenia ich liczebności. W ordynacji wyborczej do Sejmu RP przyjęto możliwość posiadania przez mniejszości własnych reprezentacji parlamentarnych. Zaszły ważne zmiany dotyczące wspólnot religijnych i Kościołów grupujących ich członków, przyznano im m.in. prawo do dni wolnych od pracy w okresie świąt przypadających w innym terminie niż święta katolickie. Mniejszości zyskały prawo do czasu antenowego w mediach, szkolnictwa i nazewnictwa miejscowości (po spełnieniu określonych warunków) (Chodubski 2016) ${ }^{7}$. Bambrzy, niebędący już wówczas mniejszością etniczną, lecz rozproszonymi członkami grupy etnograficznej o obcych korzeniach etnicznych, w sposób widoczny ulegli

${ }^{7} \mathrm{~W}$ styczniu 2005 r. Sejm przyjął Ustawę o mniejszościach narodowych i etnicznych oraz o języku regionalnym. 
tej atmosferze, sprzyjającej publicznemu manifestowaniu swojego szczególnego charakteru i tożsamości.

Niebanalną rolę w ich reaktywacji odegrała zatrudniona w IAE PAN w Poznaniu profesor Maria Paradowska (zmarła w 2011 r.) $)^{8}$. Zainteresowała się ona osadnikami bamberskimi znacznie wcześniej, pod koniec lat 50. XX w., jeszcze jako studentka etnografii na poznańskim Uniwersytecie im. Adama Mickiewicza. Jako pierwsza podjęła badania naukowe nad tą grupą, a ich efektem była praca magisterska z 1960 r., a następnie oparta na niej monografia Bambrzy. Mieszkańcy dawnych wsi miasta Poznania. Książka, nim się ukazała, wiele lat przeleżała w cenzurze i została wydana dopiero w 1975 r. Nawet wówczas nie zdobyła jednak popularności, nie był to temat szczególnie nośny w przestrzeni publicznej. Powrócono do niej właśnie na fali zainteresowania różnymi mniejszościami, w latach 90. XX w. Przełomowy okazał się rok 1993, kiedy Maria Paradowska (już profesor) została poproszona o wygłoszenie dwóch odczytów na temat Bambrów (w lutym i w czerwcu 1993 r.) na zaproszenie Towarzystwa Miłośników Miasta Poznania. Zatytułowała je „Rodziny bamberskie w Poznaniu". Jak sama wspominała, spotkania przyciągnęły tłumy. W toku dyskusji po jednym z nich wyłonił się pomysł stworzenia organizacji skupiającej członków rodów bamberskich i osoby zainteresowane tą tematyką. Okoliczności powołania stowarzyszenia skupiającego potomków Bambrów stają się dziś „,mitem założycielskim” tej grupy.

Pierwotnie już 1 lipca 1993 r. przy wsparciu Marii Paradowskiej uformowało się Koło Bambrów Poznańskich. Badaczka zadbała, by poinformować o tym media (prasa lokalna, radio i telewizja) i dlatego na fali popularności pod koniec roku stowarzyszenie liczyło już 120 osób. Przewodniczącym został Bamber - Jan Sznajder. Niektórzy członkowie uważali jednak, że na czele powinna stanąć prof. Paradowska, która była najbardziej zaangażowana w działalność Koła. Dzięki jej kontaktom naukowym współorganizowało ono otwartą w październiku 1995 r. wystawę w Muzeum Historii Miasta Poznania pt. „Z szuflad i strychów pradziadków. Wystawa pamiątek rodzinnych Bambrów poznańskich". W ten sposób jeszcze bardziej przybliżono poznaniakom tę grupę. W tym samym roku na fali rosnącego zainteresowania Bambrami ukazało się zmienione i rozbudowane kolejne polskie wydanie najpopularniejszej książki prof. Paradowskiej pt. Bambrzy. Mieszkańcy dawnych wsi miasta Poznania

\footnotetext{
${ }^{8}$ Na temat prof. Marii Paradowskiej zob. także: A. Szczepaniak-Kroll, A. Szymoszyn (2019).
} 
(wcześniej, w 1994 r., opublikowano niemieckojęzyczną wersję pierwszego wydania), które spotkało się z dużym zainteresowaniem. Za czasów działalności Koła Bamberki w barwnych sukniach ponownie pojawiły się na procesjach Bożego Ciała, co miało podkreślić silny związek tożsamości grupy z wyznaniem katolickim. W 1993 r. występowały podczas jednej z nich, trzy lata później brały już udział w kilku.

Ze względu na brak osobowości prawnej dalszy rozwój Koła był jednak niezwykle utrudniony i ostatecznie 31 grudnia 1995 r. zostało ono rozwiązane, co nie oznaczało jednak rezygnacji z dalszej działalności jego członków na rzecz Bambrów. Cztery miesiące później, 30 kwietnia 1996 roku, powstało Towarzystwo Bambrów Poznańskich (TBP), a poznańską badaczkę wybrano na jego prezeskę. Liderzy wspólnot mniejszościowych zwykle postrzegani byli i są nadal w polskiej przestrzeni kulturowej jako ludzie z pasją społecznikowską oraz autentyczni animatorzy życia społeczności. Często przez pryzmat ich postaw, zachowań, analizuje się następnie działania prowadzonych przez nich wspólnot (Sobecka 2014). Nie inaczej było także w tym przypadku. Maria Paradowska, mimo iż sama nie posiadała bamberskich przodków, stała się spiritus movens odrodzenia Bambrów. Niezwykle energiczna, obdarzona zdolnościami przywódczymi, skuteczna w realizacji wyznaczonych przez siebie zadań, a przy tym darzona szacunkiem ze względu na posiadany stopień naukowy, była w stanie wiele zdziałać dla tej grupy.

Przede wszystkim zapewniła jej siedzibę. Bambrzy ze względu na koszty nie mogli liczyć na stałe miejsce spotkań, korzystali więc z gościnności Pracowni Etnologii IAE PAN, której w 1993 r. Maria Paradowska została kierowniczką. Przez długie lata nie posiadali komputera i telefonu, więc gabinet prof. Paradowskiej był swoistym „,entrum dowodzenia” stowarzyszenia. Jej działania okazały się efektywne. W tamtych latach najbardziej wymiernym sukcesem TBP pod przewodnictwem badaczki stało się zrekonstruowanie dawnych kobiecych strojów bamberskich, będących symbolem tej grupy. Do dziś Bamberki uświetniają w nich ważne uroczystości państwowe, miejskie i religijne. Maria Paradowska osobiście nadzorowała ich powstawanie. Najpierw firma specjalizująca się w szyciu ubrań dla grup rekonstrukcyjnych przygotowała cztery stroje damskie, następnie osiem dziecięcych, a w zasadzie dziewczęcych. Szczegółowo odtworzono również najbardziej charakterystyczne elementy ubioru damskiego - kornety. Dzięki temu jeszcze więcej Bamberek w swoich odświętnych strojach mogło brać udział w różnego rodzaju uroczysto- 
ściach. Badaczce udało się także przekonać kilka rodzin, by ufundowały różne przedmioty służące upamiętnieniu ich dziedzictwa, np. płótna na pokrowce do przechowywania strojów bamberskich czy klosze ochronne na kornety.

$\mathrm{Na}$ główne cele statutowe swej działalności TBP wyznaczyło zintegrowanie środowiska potomków Bambrów, dążenie do zachowania i kultywowania ich tradycji jako integralnej części tradycji poznańskiej i wielkopolskiej, dbałość o ocalałe zabytki bamberskie oraz upowszechnianie wiedzy o tej grupie osadników ${ }^{9}$. Maria Paradowska z właściwą sobie energią przystąpiła do ich realizacji. Członkowie TBP już krótko po rozpoczęciu swojej działalności uczestniczyli w Dniu Kultury na pl. Wolności w Poznaniu, na którym zaprezentowali stoisko obok innych organizacji pozarządowych. Natomiast badaczka, w związku z coraz bardziej aktywną działalnością Towarzystwa i jego utrwalającą się symboliczną rolą w życiu kulturalnym Poznania, wygłaszała liczne wykłady i odczyty. Udzielała też wywiadów na tematy związane z Bambrami w polskiej i niemieckiej prasie, radiu i telewizji. Jako osoba zasłużona dla miasta reprezentowała TBP na uroczystościach miejskich, wojewódzkich i państwowych. Wystąpiła w trzech filmach dokumentalnych poświęconych osadnikom z okolic Bambergu ${ }^{10}$. Czuwała nad poprawnością ich scenariuszy. Szczególnie wyczulona była na często popełniany przez media błąd, polegający na określaniu Bambrów mniejszością niemiecką, za którą się nie uważali.

W 1996 r. za sprawą prof. Paradowskiej do stałego kalendarza świąt bamberskich weszły doroczne obchody na Starym Rynku w pierwszą sobotę po 1 sierpnia, upamiętniające zawarcie przez osadników pierwszego kontraktu z podpoznańskim Luboniem. Do dziś przyciągają one tłumy mieszkańców miasta i turystów. W zarządzie ustalono stały scenariusz ich przebiegu. Do najważniejszych punktów należało odczytanie pierwszego dokumentu lokacyjnego. Następnie dekorowano girlandą studzienkę z figurą Bamberki zlokalizowaną tuż przy ratuszu. Kolejnym corocznym

9 Towarzystwo Bambrów Poznańskich, Statut, https://www.bambrzy.poznan.pl/ node/13 (dostęp: 15.04.2020 r.).

${ }^{10}$ Były to filmy: Barbary Fabiańskiej Bambrzy Poznańscy (1997), Piotra Zarębskiego Bamberska pieśń, poznańskie kuranty (1998) oraz Przyszliśmy tu z Bambergu (2002 r.) autorstwa poznańskich dziennikarzy Katarzyny Kmity-Nowackiej i Jacka Zakrzewskiego dla Działu Publicystyki Programu Pierwszego Telewizji Polskiej. Maria Paradowska, Towarzystwo Bambrów Poznańskich, strona internetowa miasta Poznań, https://www. poznan.pl/mim/turystyka/-,p,4791,4795.html (dostęp: 15.04.2020 r.). 
elementem święta było wręczenie nagrody - Złotej Bamberki (od 2000 r. indywidualnie numerowanej) - osobom najbardziej zasłużonym dla osadników i ich potomków oraz dla Poznania. Nagrodzeni zostali m.in. prezydent miasta Ryszard Grobelny, wiceprezydent Tomasz Kayser (z rodziny bamberskiej), prezes Międzynarodowych Targów Poznańskich i były ambasador Polski w Niemczech Andrzej Byrt (wżeniony w rodzinę bamberską Deierlingów).

W 2000 r., jak opisywała sama prof. Paradowska ${ }^{11}$, w czasie uroczystości można było zjeść pyry z gzikiem (ziemniaki z twarogiem wymieszanym ze śmietaną, szczypiorkiem i rzodkiewką), rumpuć (gęsta zupa jarzynowa), sznytke chleba ze smoloszkiem i skrzyczkami (kromka chleba ze smalcem i skwarkami). Co do większości z nich nie ma pewności, że zostały przeniesione $\mathrm{z}$ Bambergu, lecz $\mathrm{w}$ tej chwili utrwaliło się już przekonanie, że należą do bamberskiej kultury. Ponadto odbywały się konkursy gwary poznańskiej, a także sztrykowania (robienia na drutach) i heklowania (szydełkowania), noszenia wody w węborkach (wiadrach) zawieszonych na szuńdach (nosidłach), obierania i ucierania pyrek (ziemniaków), strugania sztekla ${ }^{12}$ i gry w zośkę ${ }^{13}$, a dla dzieci konkursy rysunkowe, m.in. na najładniejszy rysunek bamberki. Można było też przejechać się bryczką po Starym Rynku. Święto uatrakcyjniały muzyką i śpiewem zespoły artystyczne. Bamberki w strojach roboczych pomagały w sprzedaży warzyw, owoców, pieczywa oraz książek i folderów o osadnikach. W kolejnych latach pojawiały się podobne atrakcje ${ }^{14}$.

Prezeska starała się podejmować opisane działania, by zapewnić grupie właściwe miejsce w historii i bieżącym krajobrazie kulturowym miasta. Strój bamberski miał być jej najbardziej widomym znakiem. Zżymała się, kiedy w uroczystościach państwowych organizowanych w Poznaniu, a szczególnie w uroczystościach miejskich (jak np. Imieniny ulicy Święty

11 Maria Paradowska, Święto bamberskie, strona internetowa miasta Poznań, https://www.poznan.pl/mim/turystyka/swieto-bamberskie,p,4791,4796.html (dostęp: 20.04.2020 r.).

${ }^{12}$ Sztekiel - podwórkowa stara poznańska gra polegająca na podbiciu obustronnie zaostrzonego krótkiego patyka (sztekla) grubym kijem i uderzaniu go w powietrzu na jak największą odległość. Poznańska Wiki, hasło sztekiel, https://poznan.wikia.org/wiki/ Sztekiel (dostęp: 14.05.2020 r.).

${ }^{13}$ Polegała na podbijaniu piłeczki stopa.

14 Maria Paradowska, Święto bamberskie, strona internetowa miasta Poznań, https://www.poznan.pl/mim/turystyka/swieto-bamberskie,p,4791,4796.html (dostęp: 20.04.2020 r.). 
Marcin), występowały kobiety w strojach góralskich lub łowickich, przekonując, że w tej roli, w tym miejscu, powinny występować Bamberki.

Maria Paradowska szybko stała się w Poznaniu osobą publiczną, powszechnie znaną i poważaną. Obdarzona była charyzmą, jaką mogło się poszczycić niewielu innych liderów stowarzyszeń. Pod koniec XX w. zaistniała szansa, by ,jej” grupę osadników spopularyzować nie tylko w Polsce, lecz także poza granicami. Kiedy w Urzędzie Wojewódzkim pojawił się pomysł, by Bamberki dodały kolorytu szczytowi weimarskiemu zorganizowanemu 21 lutego 1998 r., z udziałem prezydentów Jacques'a Chiraca, Helmuta Kohla i Aleksandra Kwaśniewskiego ${ }^{15}$, prof. Paradowska nie wahała się przyjąć zaproszenia. Następnie, tym razem dzięki jej staraniom, kobiety w bamberskich strojach uświetniły spotkanie premiera Jerzego Buzka z kanclerzem Niemiec Gerhardem Schröderem w Czerniejewie koło Gniezna 27 kwietnia 2000 r., a także zjazd milenijny premierów Polski, Węgier, Czech, Słowacji i Niemiec w Gnieźnie 28 kwietnia 2000 r. Marzeniem Bambrów i prof. Paradowskiej, prywatnie bardzo związanej z Kościołem, było, by Bamberki uczestniczyły w czasie pielgrzymki Jana Pawła II w 1999 r. w mszy w Licheniu. Udało się to jednak tylko połowicznie, dziewczęta bowiem jej zdaniem usadzono zbyt daleko od papieża, by mogły zostać dostrzeżone.

W kolejnych latach ich stroje można było podziwiać na różnego rodzaju wystawach, promocjach książek, jubileuszach, spotkaniach w szkołach wszystkich stopni oraz w muzeach. Były one zawsze pretekstem do przybliżania ludziom historii i kultury Bambrów. W ten sposób faktycznie zdobywali oni sławę, która przekroczyła granice regionu.

W planach prof. Paradowskiej znalazło się jeszcze uczynienie poznańskich rodzin pochodzenia niemieckiego głównym przedmiotem badań Instytutu Archeologii i Etnologii PAN Oddział w Poznaniu, co jednak nie do końca się udało. Tematyka bamberska na stałe powróciła do Pracowni Etnologii dopiero w 2000 r. Wówczas badaczka przygotowała projekt „Współczesność i przeszłość potomków osadników z Bambergu” (zakończony w 2006 r.), który realizowała wraz ze mną począwszy od 1999 r. ${ }^{16}$.

${ }^{15}$ W 2018 r. przypomniała o tym fakcie „Gazeta Wyborcza”, zob. Bojarski, P., 20 lat temu mieliśmy szczyt weimarski w Poznaniu. Przyjechali na sandacza, prosię i piwo od Kulczyka, Gazeta Wyborcza 2018, 26 II, http://poznan.wyborcza.pl/poznan/7,109268,23063201,20-lat-temu-mielismy-szczyt-weimarski-w-poznaniu-przyjechali.html (dostęp: 24.01.2019r.).

16 Przykładowe artykuły Marii Paradowskiej z tego okresu (2001, 2003a, 2003b, 2004). 
Rezultatem pogłębiania zainteresowania naukowego Pracowni Bambrami było podjęcie współpracy z Uniwersytetem w Bambergu - Otto-Friedrich-Universität. W latach 2000-2005 w ramach dwustronnej umowy prowadziłam tam prace badawcze: wywiady z mieszkańcami miasta i poszukiwania $\mathrm{w}$ trzech archiwach ${ }^{17}$. Współpraca naukowa koordynowana była ze strony niemieckiej przez prof. Klausa Gutha, a z polskiej przez prof. Marię Paradowską. Niemiecki etnolog wystąpił następnie z inicjatywą zaproszenia kierowniczki IAE PAN jako honorowego gościa na otwarcie wystawy „Ansichtskarten erzählen Geschichte / Pocztówki opowiadają historię; Die Stadt Posen 1896-1918 / Miasto Poznań 1896-1918”, prezentowanej w latach 2000-2001 w Stadtarchiv (Archiwum Miejskim) w Bambergu ${ }^{18}$.

Współpraca z Bambergiem nie ograniczała się do kwestii naukowych. Była rezultatem nawiązanych już wcześniej kontaktów z jego władzami i mieszkańcami. Zostały one zadzierzgnięte tuż po powstaniu TBP, w 1997 r. W ich zainicjowaniu po stronie niemieckiej szczególnie zasłużył się miejscowy radny Gerhard Krischker - pisarz, poeta, właściciel wydawnictwa C.C. Buchners Schulbuchverlag i radny miejski. W czasie, kiedy zakładano TBP, odwiedził on Polskę w swej prywatnej podróży, podążając śladami ulubionego niemieckiego kompozytora E.T.A. Hoffmanna ${ }^{19}$. W centrum miasta, na Starym Rynku, na pomniku Bamberki Krischker przeczytał informację o przybyciu osadników z Frankonii, która go zaintrygowała i skłoniła do zapoznania się z tą historią i działalnością TBP. Po powrocie do Bambergu namówił tamtejszego burmistrza Herberta Lauera do zaproszenia członków Towarzystwa, do czego doszło po raz pierwszy już w 1997 r. Warto jeszcze podkreślić, że w dalszych działaniach bamberskiego radnego wspierała zatrudniona w jego firmie Katharina Wargin (z pochodzenia Polka), która następnie wielokrotnie pełniła funkcję tłumaczki w czasie spotkań członków TBP z bamberczykami. Tę pierwszą delegację do Bambergu zorganizowała prof. Maria Paradowska.

Wzajemne relacje bujnie rozwijały się za czasów sprawowania urzędu Oberbürgermeistera przez wspomnianego Herberta Lauera, w latach

${ }^{17}$ Na podstawie wspomnianych badań i zebranych materiałów w Pracowni Etnologii powstał cykl artykułów mojego autorstwa (np. Szczepaniak-Kroll 2002, 2004, 2005), dysertacja doktorska (w 2008 r., napisana pod kierunkiem prof. Paradowskiej) oraz książka (2010).

${ }^{18}$ Najpierw od 15.03.1998 r. do 26.07.1998 r. w Muzeum Historii Miasta Poznania, następnie w kilku miastach Niemiec.

${ }^{19}$ W latach 1800-1802 E.T.A. Hoffmann zamieszkiwał w Poznaniu. 
1996-2006. Burmistrz wraz z innymi mieszkańcami miasta kilkakrotnie składał wizytę w Poznaniu (pierwszą już jesienią 1997 r.). Jego pobyt za każdym razem przygotowało TBP. Był gościem prezydenta Poznania Wojciecha Szczęsnego-Kaczmarka (urzędującego w latach 1990-1998) i jego następcy Ryszarda Grobelnego (który urzędował w latach 19982014). Po wizytach następowały rewizyty, a poznańskich Bambrów i przedstawicieli Urzędu Miasta wielokrotnie zapraszano do Urzędu Miasta (Stadtrat) w Bambergu. Przy okazji nawiązane zostały kontakty z tamtejszym biskupstwem, które utrzymywane są do dziś. Z czasem poznańscy Bambrzy zawarli przyjaźnie z bamberczykami na niwie prywatnej, większość z nich trwa do dziś, już ponad 20 lat. Herbert Lauer, Katharina Wargin oraz Gerhard Krischker zostali laureatami Złotej Bamberki.

W swojej pracy prof. Paradowska mogła liczyć na pomoc innych członków zarządu i współpracowników. W 1997 r. w zarządzie Towarzystwa pojawił się Ryszard Skibiński, obecny jego prezes ${ }^{20}$. Ponadto zasiadali w nim m.in. Aleksander i Juliusz Kubel ${ }^{21}$ (z rodziny Leitgeberów) oraz dr Maciel Stolzmann (niemający korzeni bamberskich), którzy do dziś są zaangażowanymi członkami. W prace na rzecz współpracy z Bambergiem włączeni byli również wszyscy etnolodzy z IAE PAN (niezależnie od realizowanych tematów). Profesor Paradowska zlecała asystentom wymianę korespondencji, thumaczenia i wszelkie czynności organizacyjne, zwłaszcza kiedy przyjeżdżali goście z Niemiec.

${ }^{20} \mathrm{O}$ jego przystąpieniu do TBP zadecydował przypadek. Skibiński nie pochodził z rodziny bamberskiej, Bamberką ,po matce” była natomiast jego żona. W rodzinie nie interesowano się jednak szczególnie korzeniami, z wyjątkiem szwagierki przyszłego prezesa. To ona miała udać się do Bambergu ze wspomnianą pierwszą delegacją do Nadburmistrza Lauera. Niestety tuż przed dniem wyjazdu musiała zrezygnować, w zastępstwie pojechał więc Ryszard Skibiński. Wcześniej zapisał się do TBP, aby - jak sam wspominał - w jakiś sposób uzasadnić swój udział w tym wydarzeniu. Po powrocie poszedł po raz pierwszy na zebranie Towarzystwa, a kiedy dowiedział się o planowanym przyjeździe Herberta Lauera, którego poznał w Bambergu, ponownie zgłosił się do pomocy przy organizacji tej wizyty. Profesor Paradowska, obserwując jego zaangażowanie (także przy innych przedsięwzięciach), zaproponowała, by został członkiem zarządu.

${ }^{21}$ Bracia Kublowie są znanymi w mieście postaciami, znawcami miejscowej gwary, doskonałymi komentatorami wydarzeń związanych z Bambrami. Juliusz Kubel zasłynął jako autor tekstów znanych wszystkim poznaniakom radiowych audycji Blubry Starego Marycha. Ostatnio także dokonał przekładu na poznańską gwarę Małego Księcia (Nagrygol mi baranka) Antoine'a de Saint-Exupéry'ego i Misia Puchatka (Miś Szpeniolek) Alana Aleksandra Milne'a. 
Już w czasie pierwszej wizyty w Bambergu u prof. Paradowskiej pojawił się pomysł utworzenia w Poznaniu muzeum Bambrów. Zainspirowało ją Gärtner und Häcker Verein Museum, mieszczące się w dawnym domu bamberskiego ogrodnika. Zrekonstruowano w nim stroje regionalne, zaprezentowano także wyposażenie. Po powrocie badaczka od razu przystąpiła do realizacji swojej idei. Jeśli chodzi o lokalizację poznańskiego muzeum, brano pod uwagę różne możliwości, m.in. stary bamberski dom w pobliskim Luboniu czy powozownię na Woli. Ostatecznie prof. Paradowska uznała, że najlepszy będzie teren poznańskiego Muzeum Etnograficznego, stanowiącego z kolei część Muzeum Narodowego w Poznaniu. Miał to być całkowicie nowy obiekt. Członkowie TBP zaczęli zbierać pieniądze od sympatyków - darczyńców, zlecono przygotowanie projektu.

Wiele wskazywało na to, że prof. Paradowska ponownie osiągnie swój cel. W czasie budowy pojawiły się jednak duże problemy z finansowaniem. Część funduszy zebrano od sponsorów, kolejną przyznał Urząd Miasta Poznania. Z obietnicy współfinansowania wycofał się natomiast Urząd Marszałkowski, doprowadzając inwestycję niemal do bankructwa. Ostatecznie dług uregulował Urząd Miasta. Problematyczna była jednak kwestia własności budynku. Formalnie przynależał on do Muzeum Narodowego (mimo że nie brało ono udziału w finansowaniu tej inwestycji), które nie chciało oddać go w użytkowanie Bambrom. Sprawę uregulowano w ten sposób, że budynek od Muzeum Narodowego wydzierżawiło miasto i przekazało go TBP. Duży udział w jej rozwiązaniu miał, obok prof. Paradowskiej, wspomniany już Juliusz Kubel. Przyjęta wówczas formuła funkcjonowania muzeum utrzymuje się do dziś22 . Historia finansowania Muzeum bamberskiego pokazuje jednocześnie rolę władzy, finansującej rozmaite przedsięwzięcia kulturowe i tym sposobem decydującej o możliwości rozwijania określonych tożsamości ${ }^{23}$. Magistrat jest

22 Historię powstawania muzeum opisała Anna Plenzler w artykule pt. Miasto spłaciło dtug za budowę Muzeum Bambrów Poznańskich, „Głos Wielkopolski”, 28.10.2008, https://gloswielkopolski.pl/miasto-splacilo-dlug-za-budowe-muzeumbambrow-poznanskich/ar/56229 (dostęp: 16.04.2020 r.).

${ }^{23}$ Poznańskie władze wraz ze zmianami ustrojowymi zapoczątkowanymi w 1989 r. przyjęły stanowisko, że czynniki kulturowe wyznaczające odmienność regionu są niezwykle ważne, ponieważ bezpośrednio wpływają na wyniki gospodarcze i rozwój, a tym samym na jego konkurencyjność (Dziembowska, Kowalska, Funck, 2000). Dofinansowują więc działania Bambrów, będących swoistą wizytówka regionu. Tego rodzaju działania wpisują się w proces określany w języku angielskim mianem heritagization. Twórca tego terminu Kevin Walsh (1992: 4) mówił, że jest to zmienianie rzeczywistych miejsc w turystyczne przestrzenie, zwracał przy tym uwagę na destrukcję kultury przez 
do dziś głównym źródłem finansowania przedsięwzięć Bambrów - poza sponsorami. Tylko raz w swojej historii Maria Paradowska skorzystała dodatkowo ze wsparcia Fundacji Współpracy Polsko-Niemieckiej.

Problemy z budową placówki kosztowały prezeskę TBP wiele stresu i poświęcenia. Konieczność pokonywania piętrzących się urzędowych trudności, wydających się barierą nie do przejścia, niejednokrotnie stawiała pod znakiem zapytania ciąg dalszy starań o tę instytucję. Jednak dzięki determinacji i zaangażowaniu całego TBP pod kierownictwem Marii Paradowskiej ostatecznie muzeum powstało w 2003 roku. W salach mieszczących się na dwóch kondygnacjach, odtworzono wnętrza typowego XIX-wiecznego zamożnego bamberskiego domu z kuchnią, sypialnią $\mathrm{i}$ alkową. Zaprezentowane zostały także przedmioty związane z codziennym życiem osadników i ich potomków, w sumie ponad 1,5 tys. eksponatów podarowanych bądź wypożyczonych od Bambrów.

Pierwszym kierownikiem tej powołanej z inicjatywy społecznej instytucji wybrano, jak można było się spodziewać, Marię Paradowską. Jej główną troską było to, by w muzeum Bambrzy mieli wreszcie po wielu latach swoją siedzibę, by znalazło się tam pomieszczenie do pracy naukowej, organizowania wykładów, gromadzenia archiwaliów, materiałów, opracowań i eksponatów, przechowywania strojów, jak również innych akcesoriów bamberskich. Cele i tym razem zostały zrealizowane. Bambrzy opuścili IAE PAN przy ul. Zwierzynieckiej i rozpoczęły się ich spotkania w muzeum, cykliczne, odbywające się co dwa miesiące (zarząd spotykał się częściej). Omawiano na nich bieżące sprawy, plany do zrealizowania, organizację imprez z udziałem Bamberek, zapraszano także gości z wykładami na tematy związane z historią i kulturą Poznania.

U progu nowego tysiąclecia prof. Paradowską także w sensie naukowym całkowicie pochłonęła bamberska tematyka. Została autorką przewodników i informatorów o dziejach i kulturze Bambrów, jak: Poznań. Zabytki bamberskie. Przewodnik (2002 i 2008), również w wersji niemieckojęzycznej - Poznań. Bamberger Spuren. Stadtführer (2002), czy Muzeum Bambrów Poznańskich (informator w języku polskim i niemieckim 2010). Napisała także niewielką książeczkę O historii Bambrów ina-

turystykę. W kolejnych latach zaczęto w ten sposób określać proces konstruowania dziedzictwa. Według Roigé i Frigolé (2010: 12) jest to „proces kulturowej produkcji, w której kulturowe albo naturalne elementy są selekcjonowane i przerabiane dla nowego społecznego użytku". W kontekście Bambrów chodzi o odbudowanie i ożywienie dziedzictwa kulturowego, którego są częścią, w celu wykreowania pożądanego wizerunku miasta. 
czej (Poznań 2003). W latach 2000-2006 pełniła funkcję redaktorki czasopisma „Ethnologia Polona”, wydawanego przez IAE PAN, w którym publikowała również artykuły na temat Bambrów. Wiele z nich zamieściła w „Kronice Miasta Poznania” jako jeden z wielu autorytetów wśród badaczy historii i kultury miasta.

W 2003 r. IAE PAN ze względów finansowych przeniesiony został do Poznańskiego Parku Naukowo-Technologicznego Fundacji UAM przy ul. Rubież 46. Ten fakt wpłynął na działalność badawczą Marii Paradowskiej, która była już w zaawansowanym wieku. Do Instytutu zaglądała coraz rzadziej, głównie z powodu trudności z dojazdem. Dalej zajmowała się natomiast sprawami bamberskimi jako prezeska TBP, kierując nim głównie z muzeum, zlokalizowanego niedaleko jej miejsca zamieszkania. Nie było to jednak łatwe, ponieważ wykryto u niej chorobę nowotworową, która szybko postępowała.

W 2009 r. jako prezeska Towarzystwa Bambrów Poznańskich otrzymała prestiżową Europejską Nagrodę Obywatelską przyznaną Towarzystwu przez Parlament Europejski za inicjatywy zbliżające ku sobie narody, w tym przypadku - polski i niemiecki. Miało to związek z działalnością prof. Paradowskiej w Towarzystwie oraz na rzecz partnerstwa miast - Poznania i Bambergu. Do tej nagrody zgłosił ją europoseł Filip Kaczmarek (PO). Przyznano jej również Krzyż Kawalerski Orderu Odrodzenia Polski (2003) oraz Złoty Krzyż Zasługi (1993), a także odznakę ,Zasłużony Działacz Kultury” (1995). Dostrzeżono również zasługi prezeski jako kobiety. Czasopismo „Pani” uznało ją w roku 1999 za jedną ze 100 wybitnych kobiet, co potwierdził także Business and Professional Women's Club, ogłaszając ją Kobietą Roku 2005. Wielkopolskie Towarzystwo Kulturalne uhonorowało prof. Paradowską Pegazem Wielkopolskim. Otrzymała również medal Fundacji Ochrony Zabytków Wielkopolski (2005) oraz prestiżowy medal „Ad Perpetuam Rei Memoriam” przyznawany przez wojewodę wielkopolskiego (2003). Towarzystwo Bambrów Poznańskich w czasie prezesury badaczki zyskało tytuł „Zasłużony dla Miasta Poznania". Maria Paradowska zmarła 9 stycznia 2011 roku w Poznaniu. Pozostawiła znaczny dorobek naukowy, była autorką 16 książek i ponad 200 artykułów. Duża część tych publikacji dotyczyła Bambrów. 
Agnieszka Szczepaniak-Kroll

Ocena działalności Marii Paradowskiej jako prezeski TBP

Podsumowując działalność poznańskiej badaczki, można stwierdzić, że przyczyniła się ona do odrodzenia i zintegrowania osadników jako grupy. Bambrzy zyskali swoją organizację, siedzibę, miejsce eksponowania materialnego dziedzictwa i badań nad dziedzictwem niematerialnym. W efekcie podjętych działań doszło również do wzmocnienia tożsamości potomków bamberczyków, której ważnym elementem było pochodzenie i związana z nim kultura. Udało się odbudować pamięć o Bambrach w społeczeństwie Poznania i doprowadzić do wzrostu ich prestiżu, wygaszonego w czasach komunistycznych.

W tym sukcesie niezwykle istotnym czynnikiem okazał się fakt, że prezeska TBP była jednocześnie naukowcem - etnolożką i kierownikiem Pracowni Etnologii IAE PAN. Maria Paradowska nie tylko zapewniła Bambrom „dach nad głową” w swym miejscu pracy, lecz także uczyniła ich sprawy ważnymi, bo wspieranymi przez autorytet. Dzięki kompetencjom naukowym rozumiała, czym jest dziedzictwo kulturowe i jaka jest jego wartość. Zwracała uwagę na jego materialne aspekty - jako pierwsza opisała zabytki bamberskie w Poznaniu: domy, kapliczki, z których fundowania szczególnie zasłynęli Bambrzy, budynki gospodarskie, krzyże i pomniki. Zrekonstruowała stroje bamberskie i utrwaliła je w świadomości poznaniaków jako symbol osadników. Przyczyniła się do zgromadzenia, tezauryzacji i wyeksponowania bamberskich „rzeczy”, przedmiotów codziennego użytku, narzędzi, fotografii i innych pamiątek. Jednocześnie uświadomiła innym, że dziedzictwo to nie tylko materialne dobra kultury, ale także, a może przede wszystkim, pamięć przekazywana następnym pokoleniom, zawierająca historie rodzinne, opowieści o zwykłym życiu i odświętnych momentach, o tym, co ważne i co budzące niechęć, o swojskości i obcości. Tę pamięć Barbara Szacka (2012: 16) zdefiniowała jako „zbiór wyobrażeń członków zbiorowości o jej przeszłości, o zaludniających ją postaciach i minionych wydarzeniach, a także sposoby ich upamiętniania i treści przekazywanej o nich wiedzy, uważanej za obowiązkowe wyposażenie członka tej zbiorowości”. Tak rozumiana pamięć bardziej rekonstruowała, niż rejestrowała przeszłość, a jednocześnie krystalizowała zbiorową tożsamość (Saryusz-Wolska 2009: 20).

Prof. Paradowska wyróżniła i doprowadziła do utrwalenia pewnych elementów kultury Bambrów, jak strój, święto bamberskie, Muzeum Bambrów, zarówno w tożsamości ich samych, jak i w krajobrazie miasta. 
Stały się one specyficznymi miejscami pamięci, o których Andrzej Szpociński (2008: 15) mówił, że są to pewne zdarzenia, osoby, wytwory kulturowe, postrzegane $\mathrm{w}$ potocznej świadomości jako własność określonych grup lub zbiorowości, depozyt (symbol) wartości, rzeczy ważnych dla wspólnoty. Badaczka swoimi dokonaniami potwierdziła to, co teoretycznie założył profesor Szpociński - iż u podstaw ich konstytuowania leży poczucie więzi międzypokoleniowej. Praktyki związane z „nawiedzaniem”, podzielaniem, rozpamiętywaniem tych „miejsc” stały się formami dochowania wierności przodkom i ocalenia cennych dla potomnych wartości, idei, wzorów zachowań (Szpociński 2008: 15).

Dlatego, aby zachować niematerialne dziedzictwo Bambrów, Maria Paradowska wykorzystywała każdą okazję do rozmowy z ich potomkami, poznania wspomnień i refleksji członków grupy. Fragmenty tych rozmów (czego niejednokrotnie byłam świadkiem) zapisywała nawet na papierowych chusteczkach dostępnych pod ręką, np. na imprezach bamberskich, wierząc, że wkrótce je uporządkuje i wykorzysta do naukowej analizy. Tego zamiaru nie zrealizowała w pełni z powodu braku czasu, w większości wypełnionego działaniami na rzecz Bambrów, jak również na skutek choroby. Jej materiały pozostały jednak zdeponowane i będą dalej przedmiotem studiów w Pracowni Etnologii IAE PAN. Są one niezwykle cenne, ponieważ zawierają treści tworzące $\mathrm{w}$ tamtym czasie pamięć komunikacyjną grupy, obejmującą 2-3 pokolenia wstecz. Dziś przeszły one do zasobów pamięci kulturowej. Pełnią ważną rolę, bowiem, jak pisał Jan Assmann, pamięć kulturowa skupia w sobie ,charakterystyczny dla każdej społeczności i epoki zasób ponownie używanych tekstów wyobrażeń i rytuałów, w których pielęgnuje, stabilizuje i przekazuje ona wyobrażenie o sobie samej, dzieloną ze sobą wiedzę m.in. o przeszłości, na której opiera świadomość swojej jedności i swoistości” (Assmann 2003: 16).

Podejmowane przez Marię Paradowską kroki uświadamiały fakt, że dziedzictwo kulturowe to proces, posiadający własną dynamikę. Odzwierciedla zarówno stosunek do świata określonych dziedziczonych wartości, jak i sam sposób ich reinterpretacji (Purchla 2013: 44). To dziedzictwo jest stale odtwarzane przez grupę w relacji z otoczeniem. Dlatego twórczyni renesansu Bambrów starała się nie tylko nieustannie poszerzać wiedzę o nim, ale i promować je, uwzględniając potrzeby z jednej strony Bambrów, a z drugiej społeczeństwa. Dbała o to, by w atrakcyjny sposób bamberskie dziedzictwo prezentować i utrwalać. Nie posiadała wykształcenia z zakresu zarządzania czy promocji kultury, lecz miała doskonały 
zmysł organizacyjny. Wyuczona obserwacji etnologicznej, kierowana życiową energią, skutecznie rozreklamowała to, co u Bambrów najatrakcyjniejsze - nie tylko dla nich samych, ale i dla pozostałych poznaniaków.

Sama utożsamiała się z Bambrami ze względu na podzielane wartości, takie jak praca i religia. Równie bliski, jak osadnicy, był jej Poznań, w którym mieszkała od urodzenia i którego oczywistą część stanowili przybysze z Bambergu. Realizowała ideę glokalizacji jako filtru ratującego kulturowe dziedzictwo przed ujednolicającym wpływem globalizacji (Friedman 2001), jednocześnie wykorzystując globalną modę na lokalność (Robertson 1994).

Warto zastanowić się jednak, kim byliby dziś Bambrzy, gdyby nie profesor Paradowska. I tu możemy dostrzec również pewne kontrowersje. Pojawia się pytanie, czy prezesura naukowca z szerokimi kontaktami we władzach miasta, w instytucjach kultury, aż nadto nie wpłynęła na dziedzictwo i tożsamość tej grupy. Z literatury przedmiotu wiemy, że tożsamość kulturowa łączy się z pamięcią kulturową, która może być poddana zabiegom selekcji, wzmacniania lub kreowania w ramach istniejących dyskursów czy też konfiguracji różnych interesów oraz struktur władzy organizujących oraz ujednolicających wokół siebie daną społeczność (Gorowiec, Kapralski 2014: 491). Tożsamość zbiorowa może w tej sytuacji być odgórnie kierowanym projektem wartości i kultury symbolicznej, który ma stać się reprezentacją grupy (Paprot-Wielopolska 2019: 78). Istnieje więc obawa, że Maria Paradowska zbyt odgórnie i jednostronnie wylansowała pewne elementy ich kultury, inne pozostawiając w cieniu. $\mathrm{Na}$ tę wątpliwość nie ma jednak dziś odpowiedzi, wszelkiego rodzaju próby jej udzielenia dostarczałyby jedynie kolejnych hipotez, bez możliwości ich zweryfikowania. Pytanie, na ile zwykli Bambrzy mieli wpływ na działalność tak silnej osobowości, także pozostaje bez odpowiedzi, nie ma bowiem na ten temat odpowiednich badań. Szacunek, z jakim do dziś wspomina się Marię Paradowską, każe jedynie przypuszczać, że byli i są nadal zadowoleni z osiągniętego efektu. Faktem jest, że w obecnej postaci, o której w dużym stopniu zadecydowała prezeska, dziedzictwo Bambrów zapewnia im poczucie tożsamości i ciągłości, przyczynia się też do wzrostu poszanowania dla różnorodności kulturowej oraz ludzkiej kreatywności poza grupą. 


\section{Bambrzy pod nowym kierownictwem}

Profesor Paradowska przez kilka ostatnich lat swojego życia ubolewała nad brakiem ewentualnego następcy. Ci, który z jej zdaniem powinni byli przejąć kierownictwo TBP, nie wyrażali takiej gotowości, inni potencjalni chętni nie spełniali stawianych przez nią wysokich wymogów. Sytuacja rozwinęła się jednak w sposób spontaniczny i z pozytywnym skutkiem. Schedę po prezesce przejął jej wieloletni zastępca Ryszard Skibiński. Jak sam wyznał, przez wiele lat swego zaangażowania w Towarzystwie nie myślał, że kiedykolwiek do tego dojdzie. Choć w zarządzie był w zasadzie od początku, przez długie lata onieśmielało go grono wchodzące w jego skład, w większości złożone z osób z wyższym wykształceniem, znanych w mieście i poważanych. On sam, podobnie jak prof. Paradowska, nie miał bamberskich korzeni. Do dziś jest niezwykle skromną osobą, choć jego zdolności organizacyjne okazały się imponujące.

Jak twierdzi, zamiłowanie do działalności społecznej przejął od ojca, który udzielał się w lokalnych przedsięwzięciach. Za czasów młodości obecnemu prezesowi TBP nie podobało się to zaangażowanie, jego zdaniem odbierało mu bliską osobę. Później ojciec wielokrotnie ze śmiechem mu to wypominał. W okresie prezesury prof. Paradowskiej Ryszard Skibiński był człowiekiem stale obecnym w jej otoczeniu, lecz zawsze na drugim planie, starającym się nie wychylać, pozostającym w cieniu, mimo ogromnej pracy, którą wykonywał. Dbał o logistykę, przygotowanie i sprawny przebieg uroczystości bamberskich, organizował pobyty delegacji z Niemiec, wycieczki, spotkania, zwiedzanie przez turystów Muzeum Bambrów itd. W ten sposób zdobywał doświadczenie, które, jak się później okazało, bardzo przydało się w działalności dla TBP. 


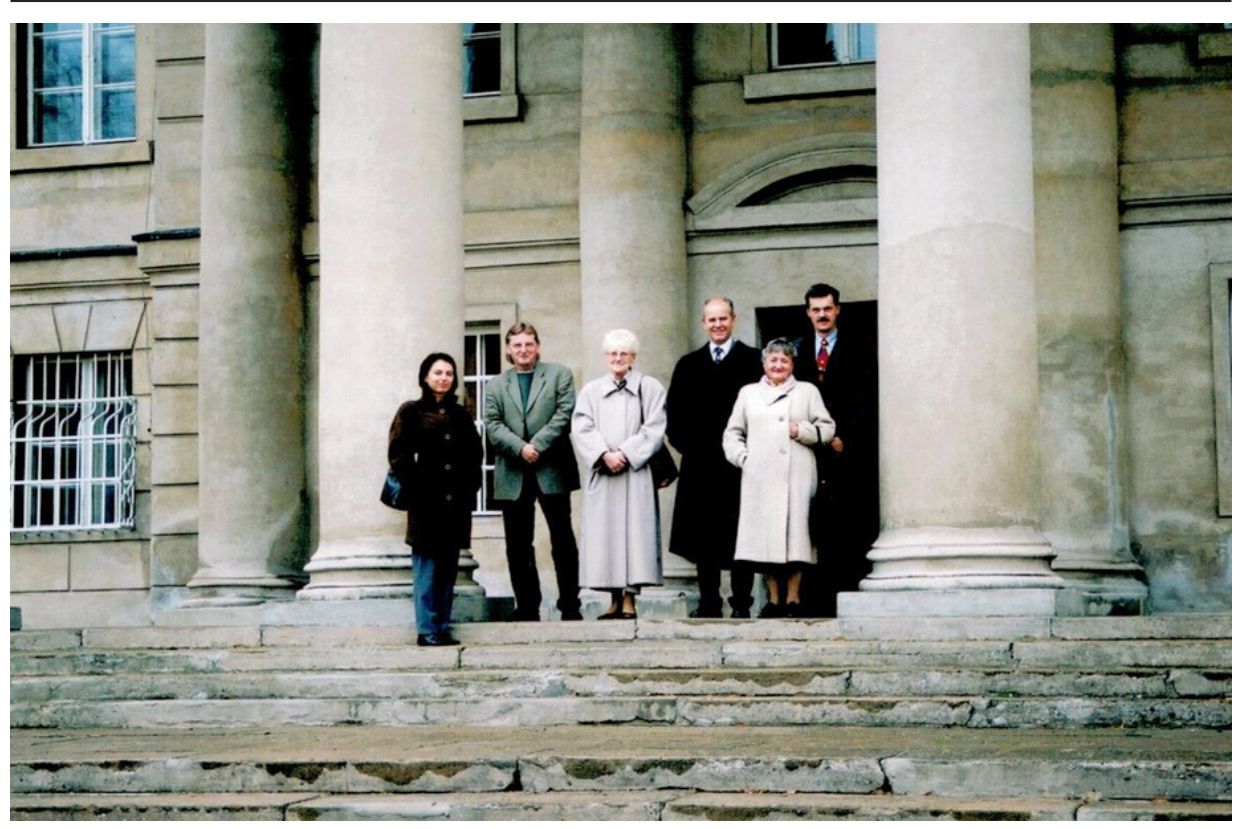

Fot 1. Wizyta nadburmistrza Bambergu Herberta Lauera w Poznaniu w 2000 r.

$\mathrm{Na}$ zdjęciu w czasie zwiedzania pałacu w Czerniejewie pod Poznaniem.

W kolejności od lewej strony stoją: Agnieszka Szczepaniak-Kroll, Gerhard Krischker, prof. Maria Paradowska, Oberbürgermeister Herbert Lauer, Urszula Muth, późniejszy prezes TBP Ryszard Skibiński. Źródło: archiwum autorki.

Zapytany o to, jaką miał wizję swojej prezesury, odpowiedział, że zamierzał po prostu „kontynuować i ubogacić” dokonania prof. Paradowskiej. Uważał, iż dziedzictwo Bambrów, jedyne w swoim rodzaju, należy „kultywować z jak największym pietyzmem. (...) jak najwięcej wyciągnąć od starych, żeby przekazać młodym. Chciałem, żeby opowiadali, dzielili się wspomnieniami, żeby to pozostało w pamięci i było przekazane następnym pokoleniom".

Najważniejszym celem nowego prezesa stało się zapewnienie Bambrom możliwości dalszych spotkań, nie rzadziej niż raz na dwa miesiące. Pod koniec życia prof. Paradowskiej ze względu na jej chorobę odbywały się one bowiem nieregularnie. Jak stwierdzał Skibiński: „wiedziałem, że kiedy przestaniemy się spotykać, to to się wszystko rozpadnie”. Utrzyma- 
no ich formułę, a liczba członków pozostawała na stałym poziomie 120130 osób. Nadal działało także bamberskie muzeum, otwierane dwa razy w tygodniu, a w sezonie turystycznym, bądź na życzenie zwiedzających, częściej. Stało się ono, tak jak przewidywała prof. Paradowska, centrum funkcjonowania Bambrów. Jego kierowaniem i prowadzeniem zajęli się sami, co od początku istnienia placówki zapisano w umowie $\mathrm{z}$ miastem. Bambrzy są z tego powodu bardzo dumni. Często w rozmowach podkreślają jego wyjątkową formułę. Natomiast faktem jest, że pozbawione zostało ono w ten sposób naukowej opieki merytorycznej, co może budzić pewien niepokój, tym bardziej że niektóre działania zespolone z muzeum podejmowane przez TBP są kontrowersyjne. Trzy lata temu wymyślono męski strój bamberski złożony z przypadkowych elementów, które współczesnym Bambrom wydały się atrakcyjne. Eksponuje się go zwiedzającym muzeum i podczas świąt bamberskich. Jak mówią członkowie stowarzyszenia, chodziło o to, by kobiety miały towarzystwo. Choćby z uwagi na takie zdarzenia pożytek przyniosłaby współpraca ze specjalistami, której rozluźnienie od śmierci prof. Paradowskiej stało się bolączką prezesa Skibińskiego.

Do jego kalendarza już na początku prezesury wpisane zostały powtarzane corocznie uroczystości, takie jak wspólne spotkanie opłatkowe, procesja Bożego Ciała, Imieniny ulicy Święty Marcin, sierpniowe święto bamberskie, msza w intencji Bambrów, obchody święta Konstytucji 3 Maja, Ogólnopolskie Spotkania Młodych LEDNICA 2000 (2015 r., 2016 r.), Lednica Seniora. Pozostałe dni wypełniały organizowane na bieżąco prelekcje w szkołach, domach kultury, dla Uniwersytetów Trzeciego Wieku, pikniki, gale i jubileusze. Uszyte zostały kolejne stroje Bamberek - 12 kompletów - oraz 18 nowych kornetów. W 2013 r. założona została strona internetowa Towarzystwa (https://www.bambrzy.poznan. $\mathrm{pl} /$ node/25) z podstawowymi informacjami i danymi kontaktowymi, natomiast w 2018 r. Bambrzy znaleźli się na Facebooku. Muzeum Bambrów włączyło się także w coroczną imprezę „Noc Muzeów”, w czasie której ekspozycja udostępniana była dla zwiedzających za darmo. Tylko w 2014 r. w tę noc Bambrów odwiedziło 3000 poznaniaków i turystów (w $2015 \mathrm{r}$. - 2000 osób, w 2016 r. - 1700). Bamberki w celach promocyjnych wzięły udział w kilku sesjach zdjęciowych, w tym w nietypowych miejscach, takich jak poznańskie lotnisko Ławica, czy Radio Merkury. W swoich barwnych strojach występowały m.in. na Targach Książki, dożynkach, 125. rocznicy Miejskiego Przedsiębiorstwa Komunikacyjnego (2014 r.), 
Dniach Agrolotnictwa w Muzeum Rolnictwa w Szreniawie (2014 r.), w obchodach rocznicy przyłączenia wsi Dębiec do Poznania (2015 r.), Święcie Niepodległości i 35-leciu Kapeli Zza Winkla (2015), Orszaku Trzech Króli (2018).

Bambrzy nieustająco kontynuowali relacje $z$ regionem pochodzenia, głównie ze względu na przyjacielskie kontakty z bamberczykami. W czerwcu 2017 r. wystąpili w tradycyjnych strojach na uroczystości wręczenia nagrody Michaelowi Niedermeyerowi, ogrodnikowi i regionaliście z „Gärtner Und Häcker Verein”, z którym od lat współpracują i wzajemnie się odwiedzają. Bambrzy z Poznania i Bambergu dwukrotnie wspólnie udawali się na pielgrzymki: do Rzymu i do Częstochowy. W Watykanie przyjęci zostali na audiencji przez papieża Benedykta XVI. W ostatnim czasie Ryszard Skibiński do współpracy zdołał włączyć mieszkająca w Bambergu dr Ewę Herber, polską prawniczkę, z zamiłowania przewodniczkę po mieście. Weszła ona do grona osób aktywnie wspierających współpracę z Poznaniem.

Ponadto z TBP kontakt nawiązał zespół szkół Maria-Ward-Schulen z Bambergu (gimnazjum i szkoła podstawowa). Uczniowie kilkakrotnie odwiedzali poznańskie Muzeum Bambrów, m.in. w latach 2015 i 2018. Za każdym razem towarzyszyli im gimnazjaliści z Lubonia z Gimnazjum nr 1 (obecnie Szkoła Podstawowa nr 3 z Oddziałami Dwujęzycznymi w Luboniu oraz Dwujęzyczne Liceum Ogólnokształcące w Luboniu) ${ }^{24}$. Lubońscy uczniowie, z którymi Niemcy nawiązali współpracę, także gościli w Bambergu, m.in. w kwietniu 2018 r. Współpracę z niemiecką Fachoberschule Berufsoberschule w Bambergu podjęło również poznańskie Liceum Ogólnokształcące nr 5. W 2018 i 2019 r. uczniowie uczestniczyli w wymianie, a jeden z niemieckich nauczycieli gościł na jubileuszu bamberskim w Poznaniu ${ }^{25}$.

Osłabł natomiast kontakt z władzami miejskimi Bambergu. Kolejny po wspomnianym Herbercie Lauerze burmistrz, Andreas Starke (od 2007 r.), urzędujący do dziś, przejawiał zdecydowanie mniejsze zainteresowanie wzajemnymi relacjami. Bambrzy oceniają, że przyczyną były jego bezpodstawne obawy o konieczność finansowania różnych wspólnych przedsięwzięć w przypadku ewentualnej współpracy. Z tego powodu w TBP

${ }^{24}$ Strona polsko-niemieckiego projektu: https://sp3lubon.pl/projekt-lubon-bambergwspolna-przeszlosc-wspolna-przyszlosc/ (dostęp: 19.04.2020 r.).

${ }^{25}$ Strona poznańskiego LO $\mathrm{nr} \mathrm{V}$ i informacja o wymianie międzyszkolnej: https:// www.vlo.poznan.pl/page.php/1/1/show/000110/ (dostęp: 19.04.2020 r.). 
powstał już nowy pomysł, by zintensyfikować kontakty, tym razem z władzami powiatowymi (Landratsamt), które reprezentują podobne stanowisko co dawny Oberbürgermeister i chętnie współpracują z wieloma europejskimi miastami (w tym m.in. z Jelenią Górą). Znajduje się on obecnie $\mathrm{w}$ fazie realizacji.

Już w 2016 r. Ryszard Skibiński rozpoczął przygotowanie do jubileuszu 300-lecia Bambrów w Poznaniu, przypadającego na 2019 r. Okazał się on wielkim świętem całego miasta, ogromnym sukcesem medialnym i promocyjnym. Dziś można ocenić, że z całą pewnością na długie lata zostanie zapamiętany przez poznaniaków i turystów. Jak podkreślał prezes, pierwszą datą, którą wpisano w związku z nim do kalendarza, była msza w intencji osadników 20 października 2019 r. Poznański arcybiskup Stanisław Gądecki bez wahania zgodził się ją koncelebrować, ze względu na bardzo dobre relacje z Bambrami. Zaproszono również biskupa Bambergu Ludwiga Schicka, od początku wyrażającego chęć przyjazdu do Poznania.

Przygotowanie tej imprezy stało się ogromnym wyzwaniem dla całego Towarzystwa, a przede wszystkim dla jego zarządu i prezesa. Do TBP zgłosiło się mnóstwo ludzi chcących się włączyć w to przedsięwzięcie. Prezes opracował specjalny kalendarz towarzyszący wydarzeniu. Zainicjowało je ogłoszenie przez Radę Miasta Poznania (8 stycznia 2019 r.) roku 2019 Rokiem Bambrów Poznańskich, co rozpoczęło serię towarzyszących temu imprez. Bambrzy zasypani zostali ofertami uczestnictwa w rozmaitych uroczystościach i spotkaniach z poznaniakami. Ryszard Skibiński stał się postacią medialną, gościł w wielu stacjach radiowych i telewizyjnych. W maju 2019 r. tłumy poznaniaków i turystów odwiedziły Muzeum Bambrów Poznańskich i Muzeum Etnograficzne, w którym zainstalowano największy na świecie kornet bamberski wypleciony z wikliny, przyozdabiany przez zwiedzających kwiatami z bibuły. To samo muzeum 28 czerwca z okazji jubileuszu otworzyło wystawę „Ty bambrze!". Szczególną atrakcją okazała się bamberska spódnica, w której wyeksponowano kilka tworzących ją warstw materiału. Każdy mógł się sfotografować na jej tle. Wystawie towarzyszyły prelekcje i program edukacyjny dla dzieci. O Bambrach, ich drodze do Poznania nakręcono także krótki, promujący jubileusz film reklamowy z udziałem samych potomków osadników ${ }^{26}$. W Luboniu - pierwszym miejscu osiedlania się

${ }^{26}$ Realizacja: Arleta Kolasińska, Rafał Jerzak, Marek Domagała, Bartosz Przybysz. Producent: Wydawnictwo Miejskie Posnania, Fundacja Artystyczno-Edukacyjna Puenta. 
przybyszów z Bambergu - planowano urządzić festyn „Biba w lasku”. Ostatecznie do niego nie doszło z powodu niepogody, powstał natomiast obelisk upamiętniający osadników i skwer imienia pierwszych osadników z Bambergu, odsłonili go przy okazji święta bamberskiego burmistrz Lubonia Małgorzata Machalska i wspomniany Gerhard Krischker z Bambergu. Z okazji jubileuszu ukazały się ponadto: kolorowanka dla dzieci, specjalny znaczek pocztowy, kalendarze, papierowe kornety, przygotowano długopisy, tzw. smycze do kluczy, przypinki, plecaki-worki i skarpetki z bamberkami jako pamiątki z Poznania.

Obchodzone corocznie święto bamberskie w 2019 r. przybrało specjalną formułę - happeningu, korowodu wiodącego od Ostrowa Tumskiego do Starego Rynku. Impreza ${ }^{27}$ przyciągnęła tysiące poznaniaków i turystów. Na Placu Kolegiackim po przemarszu Bambrów odbyła się biesiada z udziałem gości z Bambergu, w tym wiceburmistrza Wolfganga Metznera. Delegacja z Niemiec przybyła zresztą do Poznania ponownie w tym samym roku, w październiku, tym razem na czele z burmistrzem Starke. Poznańscy Bambrzy odebrali wówczas Srebrną Pieczęć Prezydenta Miasta Poznania, przyznawaną osobom, które w sposób wyjątkowy zaistniały w świadomości mieszkańców Poznania. Z kolei bamberczycy - burmistrz Starke i arcybiskup Schick - otrzymali medale okolicznościowe od Bambrów. Następnie goście z Bambergu (m.in. Herbert Lauer, Katharina Wargin i Gerhard Krischker ) wzięli wraz z poznańskimi Bambrami udział w uroczystym koncercie w Auli UAM. Spotkania niemiecko-polskie skutkowały deklaracjami zacieśnienia współpracy, co zdaniem członków TBP ma szanse przełamać dotychczasowe, zdystansowane stanowisko magistratu Bambergu w tej kwestii.

Dla Ryszarda Skibińskiego najważniejsze były jednak publikacje towarzyszące jubileuszowi. Ukazało się ich kilka, m.in. Kronika Miasta Poznania pt. Bambrzy (Mruglaska-Banaszak 2019a), album 300 lat razem. Poznańscy Bambrzy (Mrugalska-Banaszak 2019b), przewodnik po zabytkach bamberskich Śladami Bambrów (Plenzler 2019), powieść Przez zmierzchy i świty. Saga bamberska (Rausch 2019), książka naukowa 300 lat Bambrów w Poznaniu. Wkład małych wspólnot migracyjnych $w$ dziedzictwo kulturowe Polski (Brzezińska, Szczepaniak-Kroll, Szymoszyn 2019).

Ta ostatnia publikacja powstała po konferencji pod tym samym tytułem, zorganizowanej przez prof. UAM dr hab. Annę Weronikę Brzezińską

${ }^{27}$ W reżyserii Anety Kolasińskiej z Fundacji Artystyczno-Edukacyjnej Puenta. 
z Instytutu Antropologii i Etnologii Kulturowej UAM oraz dr Agnieszkę Szczepaniak-Kroll i dr Annę Szymoszyn z Instytutu Archeologii i Etnologii PAN w Poznaniu, przy wsparciu Urzędu Miasta Poznania i TBP. Bambrzy, jako jubilaci, stali się jej motywem przewodnim, lecz w monografii mowa jest także o kilku innych, pod różnymi względami podobnych do nich grupach, jak Wilamowianie, Kosznajdrzy czy olędrzy.

Inicjatywa zorganizowania konferencji wyszła od Rady Miasta Poznania, chętnie podchwycona została jednak przez Bambrów, przede wszystkim przez Ryszarda Skibińskiego. W ten sposób zacieśnili oni współpracę ze środowiskiem naukowym, przerwaną wraz ze śmiercią prof. Paradowskiej, a przywróconą rok wcześniej, w 2018 r. Wówczas Bambrzy, z pomocą A.W. Brzezińskiej (IEiAK UAM), wystąpili z pozytywnym skutkiem z wnioskiem o wpis na Krajową Listę Niematerialnego Dziedzictwa Kulturowego. W przypadku Bambrów za istotne uznano takie jego elementy jak obchody Święta Bamberskiego, udział Bamberek w paradach Świętego Marcina jako przykład tradycji świeckich, udział w procesjach Bożego Ciała jako przykład tradycji kościelnych, praktyka noszenia stroju bamberskiego oraz działalność Towarzystwa Bambrów Poznańskich podtrzymującego tożsamość grupową. Wpis na tę prestiżową listę okazał się bardzo ważnym wydarzeniem, ponieważ Konwencja UNESCO w sprawie ochrony niematerialnego dziedzictwa kulturowego z 17 października 2003 r., nakłada na państwa-strony obowiązek inwentaryzacji przejawów tego dziedzictwa znajdujących się na ich terytoriach, jego identyfikację, dokumentację, badanie, zachowanie, zabezpieczenie, promowanie, wzmacnianie i przekazywanie, w szczególności przez edukację formalną i nieformalną, jak również rewitalizację różnych aspektów tego dziedzictwa (Konwencja ... 2003). Daje to TBP (i badaczom kultury Bambrów) wiele możliwości dalszego działania, związanego z realizacją tego dokumentu.

W maju 2019 r., przy aprobacie ekspertów, Bambrzy otrzymali zaszczytną Nagrodę im. Oskara Kolberga za zasługi dla kultury ludowej (dyplom oraz pamiątkowy medal) z rąk Ministra Kultury i Dziedzictwa Narodowego - prof. dr. hab. Piotra Glińskiego. Również w rywalizacji o to trofeum mogli liczyć na wsparcie poznańskiego środowiska naukowego. 


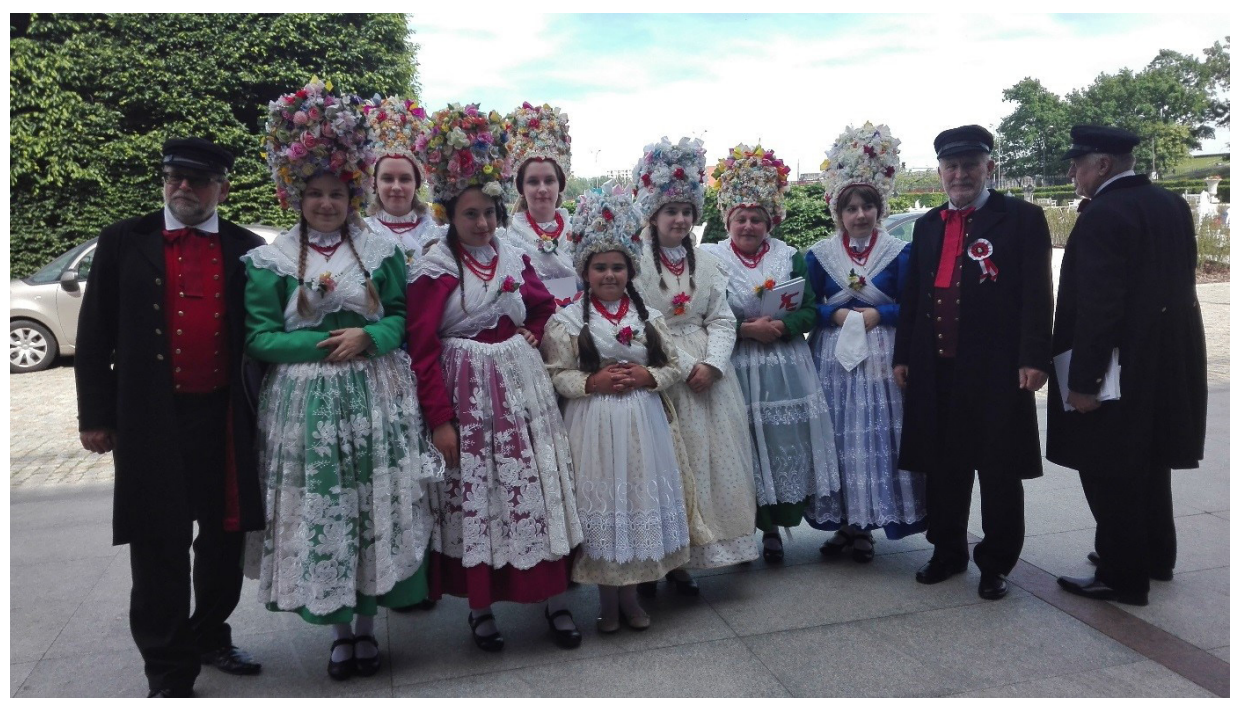

Fot. 2. Bambrzy po gali wręczenia Nagrody im. O. Kolberga w 2019 roku.

Źródło: archiwum autorki

Ryszard Skibiński, który w przeciwieństwie do prof. Paradowskiej nigdy nie prowadził działalności naukowej związanej z Bambrami, również $\mathrm{z}$ tego powodu powstałe publikacje uważa za bardzo ważny efekt jubileuszu. Innym pozytywnym skutkiem obchodów w jego opinii są miejsca, którym nadano związane z Bambrami nazwy, czyniąc je „ich miejscami”. Marię Paradowską uczyniono patronką skweru znajdującego się na Jeżycach na środku ul. Kościelnej, między ul. Poznańską a tunelem pod torami kolejowymi. Nazwę Bambrów Poznańskich przydzielono zaś nowemu parkowi na Dębinie, wzdłuż ul. Dolna Wilda.

\section{Ocena działalności Ryszarda Skibińskiego}

Obchodzony przez cały rok 2019 jubileusz 300-lecia Bambrów w Poznaniu uznany został za udany, zarówno przez Ryszarda Skibińskiego, jak i cały zarząd TBP. Bambrzy mocno ugruntowali swoją pozycję w mieście i zdobyli jeszcze więcej sympatii jego mieszkańców. Ich dorobek uhonorowany został ważnymi nagrodami i wpisem na Krajową Listę Niematerialnego Dziedzictwa Kulturowego. W bieżącym roku i w kolejnych latach może mieć to ważny praktyczny efekt - przełożyć się na skuteczność w zabieganiu o środki na realizację kolejnych działań. 
Rola liderów w kształtowaniu i promowaniu dziedzictwa...

Sam prezes pokazał, że jest godnym spadkobiercą talentu organizacyjnego prof. Paradowskiej. Dostrzegł jednak także niebezpieczeństwa związane z sukcesem. Jak mówił:

Jubileusz spowodował, że Bambrzy to jest temat nośny. W muzeum wcześniej 2-3 razy w tygodniu otwarte, a teraz do koronawirusa [zamknięcia instytucji kultury od połowy marca 2020 r. - dopisek autorki], codziennie. To jest temat nośny, a z takimi rzeczami trzeba uważać. Pojawili się niestety ludzie, którzy chcą się teraz „załapać do tego tramwaju”, a nie mają w rzeczywistości zbyt wiele do zaoferowania. (R. Skibiński, komunikacja osobista, 2020)

Przytoczona wypowiedź świadczy o tym, że prezes zdaje sobie sprawę, iż szybkie i selektywne „skonsumowanie" dziedzictwa przez osoby chcące czerpać z niego korzyści może spowodować „zbanalizowanie”, rozmywanie się jego zasobów. Skoro każdy może z niego korzystać, grozi mu utrata wyjątkowości. Podobne obawy w odniesieniu do dziedzictwa wyrażał już badacz Jacek Purchla, pisząc, że w ten sposób zagrożona jest „autentyczność stanowiąca o wartości dziedzictwa” (2013: 47). Jednocześnie zauważał on jednak, że umiejętne wykorzystanie dziedzictwa do celów marketingowych, promocyjnych, może także wzmacniać jego wartość i znaczenie. Ważne jest więc odpowiednie wyważenie tych działań. Ryszard Skibiński wydaje się również to dostrzegać i dlatego stojąc na czele TBP, nie unika współczesnych metod utrwalania i promocji kultury Bambrów, ale stara się uwzględnić obydwie racje.

Lokalność, w obrębie której prezes podejmuje swoje działania, jest dla niego wartością samą w sobie. To dlatego, nie mając bamberskich korzeni, angażuje się w działania Bambrów - poznaniaków. Z literatury przedmiotu wiemy, że lokalność odgrywa ogromną rolę w kreowaniu tożsamości społecznej, która wiąże się właśnie z przynależnością do określonej grupy, jest przez nią uwarunkowana (Mamzer 2003: 111). W procesie komunikowania się w takiej stosunkowo małej grupie jak Bambrzy, w określonej terytorialnie przestrzeni, kształtuje się ważna część ich tożsamości, oparta na historii przekazywanej kolejnym pokoleniom. Nie jest to jednak historia odwołująca się wyłącznie do faktów, lecz również do pamięci zbiorowej ${ }^{28}$, którą Pierre Nora nazywa historią drugiego stopnia. W odróżnieniu od rekonstruującej wydarzenia „historii pierwszego stopnia” opiera się

${ }^{28}$ Pierwszy opisał działanie tego fenomenu Maurice Halbwachs w La memoire collective (1939, wydanie polskie: Społeczne ramy pamięci, 1969); odróżnił „historię” jako zbiór w rozmaitym stopniu sprawdzalnych twierdzeń o faktach od „pamięci zbiorowej”, czyli zbiorowych wyobrażeń o historii. 
ona na funkcjonowaniu określonych fenomenów historycznych (francuski badacz posługiwał się terminem „metafora”) w świadomości zbiorowej (Saryusz-Wolska 2009: 20)

Zdzisław Najder (2011: 122) proponuje nazywać te miejsca węzłami pamięci, co okazuje się ciekawą propozycją w kontekście Bambrów. Jest to zdaniem naukowca zwrot bardziej metaforyczny, a zarazem semantycznie konkretniejszy od miejsc pamięci. Odnosi się do takich nazw, imion lub dat, które wiążą ze sobą ciągi skojarzeń i odniesień historycznych łączących się w całe zespoły przedmiotów pamiętania i wspominania. Ta koncepcja oddaje sposób myślenia potomków osadników i ich prezesa o przodkach. Koncentruje się ono na elementach materialnych, jak i niematerialnych dziedzictwa z przeszłości. Te pierwsze to: domy, zagrody, narzędzia, pamiątki rodzinne, bamberskie muzeum, strój oraz ostatnio dodane Skwer Marii Paradowskiej, Park Bambrów Poznańskich, luboński obelisk i skwer Pierwszych Osadników Bamberskich. Drugie z wymienionych mają postać metaforyczną, jak etos, wyznanie katolickie, kult pracy rolniczej, sposoby świętowania, przekazywanie tradycji. Są „węzłami”, wokół których koncentrują się wspomnienia członków grupy, budujące ich tożsamość.

Dzięki działalności Ryszarda Skibińskiego wymienione miejsca pamięci pozostają własnością tej, a nie innej grupy, mimo że propaguje się je szeroko poza nią. Skrywają w sobie określone, ważne z punktu widzenia bamberskiej zbiorowości wartości (idee, normy, wzory zachowań). Bodźcem do ich powstawania, zachowania i poszerzania jest świadomość przemijania i nieodwracalnej zmiany. Jak pisał Najder (2011: 123), chcemy poprzez węzły pamięci jak na kliszach fotograficznych (które same stają się dziś przedmiotem już nieużywanym, ale wspominanym) utrwalić coś, co znamy, a co znika.

Działania podjęte przez Ryszarda Skibińskiego w 2019 r. wypełniły większość wolnego czasu prezesa, wymuszały nieobecności w pracy (w firmie produkującej samochody), niejednokrotnie narażały na niesłuszne podejrzenia o czerpanie związanych z jubileuszem korzyści materialnych, jednak nie pomniejszyły jego energii dla dalszego działania. Towarzystwo pod jego kierownictwem przygotowało już szereg planów na bieżący rok. Epidemia koronawirusa może wprawdzie spowodować ich zawieszenie i przeniesienie na bardziej odległy czas, lecz Bambrzy na pewno z nich nie zrezygnują. Zaplanowano m.in. uszycie tzw. złotych czepków mężatki do strojów Bamberek, które mają być kolejnym ele- 
mentem rewitalizacji ich materialnego dziedzictwa. Zarząd TBP zamierza także w 2020 r. „udomowić” nowe, związane z Bambrami miejsca, m.in. w Parku Bambrów powiesić tablicę pamiątkową i posadzić drzewka specjalnie zarezerwowane już w Bambergu. Wszystko zależy jednak od obiektywnych możliwości realizacji tych zamierzeń.

Celem na przyszłość Ryszarda Skibińskiego jest także większe zaktywizowanie samych potomków osadników do dzielenia się wspomnieniami, refleksjami. Jak zauważa prezes, nie będzie to łatwe, bowiem „cechuje ich nieufność i zdystansowanie”. Choć to spostrzeżenie nie jest poparte żadnymi badaniami, może zawierać ziarnko prawdy, jak bowiem pokazują fakty historyczne, to właśnie dystansowi i zamknięciu w swoich rodzinach przodkowie dzisiejszych Bambrów zawdzięczali przetrwanie.

Ryszard Skibiński nadal zamierza kontynuować działania prof. Paradowskiej mające na celu zintegrowanie Bambrów, chronienie ich dziedzictwa kulturowego, upowszechnianie wiedzy o tej grupie osadników, dbałość o ocalałe zabytki bamberskie. Ostatni jubileuszowy rok dowiódł, że potrafi to skutecznie realizować. Planuje także podtrzymywać kontakty ze środowiskiem naukowym. Ta współpraca może wypełnić lukę na polu badań naukowych nad Bambrami, która pojawiła się po śmierci prof. Paradowskiej - prezesa i nakowca, poszerzyć wiedzę w zakresie ochrony dziedzictwa kulturowego i związanych z nią meandrów zarządzania. Nie umniejsza to jednak innych zasług lidera grupy Bambrów.

\section{Podsumowanie}

Jak twierdził Steward Hall (1998; za Szwed 2005), globalizacja jest związana $\mathrm{z}$ jednej strony $\mathrm{z}$ uniwersalizacją, z drugiej skutkuje fragmentaryzacją i multiplikacją tożsamości. To drugie zjawisko często stanowi wyraz glokalizacji, czyli zdolności kultur do wchłaniania wpływów, które w sposób naturalny w nich nie występowały, wzbogacających je. Te zjawiska uwidaczniają się od lat 90 . XX w. u poznańskich Bambrów. Rozwijają oni, pielęgnują i propagują oparte na pamięci dziedzictwo, wykorzystując globalny trend ,powrotu do źródeł” oraz oferowane przez światowe koncerny technologie. Stosują nowoczesne strategie promocyjne do propagowania własnej kultury. W ten sposób zachowują tożsamość, odwołującą się do przeszłości, ale włączającą nowe elementy. 
Bardzo ważną rolę w podejmowanych przez nich działaniach pełnili i pełnią nadal liderzy - niegdyś Maria Paradowska, dziś Ryszard Skibiński. Takie osoby w naukach ekonomicznych określane są mianem stakeholders, interesariuszami, czyli „osobami mogącymi wywierać wpływ lub wpływać na osiąganie celów przez organizację" (Freeman 1984: 25). Dobrze oddaje ono sprawczy charakter przywódców - specyficznych aktorów społecznych, balansujących pomiędzy kulturą a pragmatycznym zarządzaniem. Nadają oni kierunek i kreują sposoby powstawania pamięci zbiorowej Bambrów. Same bowiem centra, wokół których koncentruje się funkcjonowanie potomków osadników, a z którymi są oni związani - TBP i Muzeum - jak pisze Aleida Assmann (2018: 48):

(...) nie „mają” pamięci, ale ją sobie „tworzą”. W tym celu korzystają z pamięciowych znaków i symboli, tekstów, obrazów, rytuałów i praktyk, odnoszą się do miejsc i pomników. Poprzez takie media i ćwiczenia pamięci wpaja się jednostkom określone treści, czyniąc je tym samym nosicielami pamięci zbiorowej. Dzięki niej instytucje i organizacje „tworzą” własną tożsamość. Utworzona w ten sposób zbiorowa pamięć nie pozostawia miejsca na spontaniczność i ambiwalencję, ponieważ jest umyślnie konstytuowana i symbolicznie skonstruowana. Jest to „pamięć” woli lub też przemyślanego wyboru.

Maria Paradowska jako pierwsza wyznaczyła kierunek działań służących Bambrom, zainicjowała je, dostosowując do potrzeb i możliwości, jakie istniały w okresie jej prezesury. Ryszard Skibiński rozwinął jej dokonania i przystosował do wymogów dzisiejszych czasów. Udział takich osób, jak opisani liderzy, w kształtowaniu i pielęgnowaniu dziedzictwa kulturowego, rośnie. Coraz częściej stają się one nieodzowne w działaniach na jego rzecz. W ciągu ostatniego półwiecza zakres tego, co nazywamy dziedzictwem, uległ bowiem znacznemu rozszerzeniu. Istotną kwestią staje się rozstrzyganie, co ma w nim znaczenie, a co nie. W ogromnym stopniu zwiększa się również zakres i liczba zagrożeń, które mogą mieć niekorzystny wpływ na dziedzictwo i, co za tym idzie, wymagają interwencji. System zarządzania dziedzictwem musi więc być nastawiony na to, by móc wpływać na decyzje dotyczące potencjalnych zmian, by współpracować z innymi interesariuszami i władzami kontrolującymi otoczenie (Zarzadzanie... 2015).

Ryszard Skibiński dostrzega, podobnie jak poprzedniczka, wielorakie powiązania pomiędzy dziedzictwem a jego tłem gospodarczym, społecz- 
nym, kulturowym, które wyznaczają kierunek jego działań. Angażuje wiele różnych osób o rozmaitych doświadczeniach i wiedzy oraz uwzględnia szerszą grupę innych interesariuszy, by osiągnąć cele. Korzystają z tego Bambrzy, którzy coraz częściej zapraszani są do dyskusji na temat pojawiających się potrzeb i możliwości ich realizacji. W ten sposób mają szansę pielęgnować swoje dziedzictwo już nie tylko w sferze prywatnej, ale i publicznej, i decydować o jego kształcie. Dzięki takim liderom, jak opisani w tekście, ich przyszłość można widzieć w pozytywnych barwach. Bez odpowiedzi pozostaje jednak szereg pytań. Co by było, gdyby nie oni? Jak bamberskie dziedzictwo wyglądałoby inaczej pod innym kierownictwem? A może w ogóle nie zachowałoby się do dziś?

\section{BIBLIOGRAFIA:}

Angosino, M. (2010). Badania etnograficzne i obserwacyjne. Warszawa: Wydawnictwo Naukowe PWN.

Assmann, A. (2018). Między historia i pamięcia. Antologia. Warszawa: Wydawnictwo Uniwersytetu Warszawskiego.

Assmann, J. (2003). Pamięć zbiorowa i tożsamość kulturowa. Borussia. Kultura. Historia. Literatura, 29, 11-16.

Bär, M. (1882). Die "Bamberger" bei Posen. Posen.

Brzezińska, A.W, Szczepaniak-Kroll, A., Szymoszyn, A. (red.) (2019). 300 lat Bambrów w Poznaniu. Wkład matych wspólnot migracyjnych $w$ dziedzictwo kulturowe Polski. Poznań - Warszawa: Wydawnictwo Miejskie Poznania, Instytut Archeologii i Etnologii PAN.

Chodubski, A. (2016). 70 lat do różnorodności. Mniejszości narodowe i etniczne w Polsce. Studia Gdańskie. Wizje i rzeczywistość, XIII, 395-408.

Dziembowska, K., Kowalska, J., Funck, R.H. (2000). Cultural activities as a location factor in European competition between regions: Concepts and some evidence. The Annals of Regional Science, 14, 1-12.

Friedman, T.L. (2001). Lexus i drzewo oliwne. Zrozumieć globalizację. Poznań: Dom Wydawniczy REBIS.

Gaweł, Ł. (2012). Zarządzanie strategiczne szlakiem dziedzictwa kulturowego w świetle koncepcji stakeholders. Turystyka Kulturowa, 10, 31-40,

Gorowiec, K., Kapralski, S. (2014). Tożsamość. W: M. Saryusz-Wolska, R. Traba (red.), Modi memorandi. Leksykon kultury pamięci (s. 489-495). Warszawa: Wydawnictwo Naukowe Scholar.

Halbwachs, M. (1969). Społeczne ramy pamięci. Seria „Biblioteka Socjologiczna”. Warszawa: Wydawnictwo PWN. 
Hall, S. (1998). Cultural Identity and Diaspora. W: J. Rutherford (red.), Identity: community, culture, difference (s. 222-237). London: Lawrence Hill

Konwencja... (2003). Konwencja UNESCO w sprawie ochrony niematerialnego dziedzictwa kulturowego, sporządzona w Paryżu dnia 17 października 2003 r. Dziennik Ustaw 2011, 172/1018, 10038-10065.

Leśniewska, D. (2019). Bamberskie zagrody. W: M. Mrugalska-Banaszak (red.), Kronika Miasta Poznania. „Bambrzy” (s. 81-108). Poznań: Wydawnictwo Miejskie Posnania.

Mach, Z. (2010). Polskie tożsamości. W: W. Kociuba-Ciembroniewicz, B. Szlachta (red.), Polska XX wieku (s. 139-156). Kraków: Wydawnictwo Uniwersytetu Jagiellońskiego.

Mamzer, H. (2003). Tożsamość w podróży. Wielokulturowość a kształtowanie tożsamości jednostki. Poznań: Wydawnictwo Naukowe UAM.

Minksztym, J. (2015). Strój bamberski. Seria: „Atlas Polskich Strojów Ludowych", t. 47, cz. II Wielkopolska, z. 6. Wrocław: Polskie Towarzystwo Ludoznawcze.

Mrugalska-Banaszak, M. (2019a). 300 lat razem. Poznańscy Bambrzy. Poznań: Wydawnictwo Miejskie Posnania.

Mrugalska-Banaszak, M. (red.) (2019b). Kronika Miasta Poznania. „Bambrzy”. Poznań: Wydawnictwo Miejskie Posnania.

Najder, Z. (2011). Węzły europejskiej pamięci. W: 50/20. Szkice i eseje na dwudziestolecie Międzynarodowego Centrum Kultury (s. 220-229). Kraków: Międzynarodowe Centrum Kultury.

Paprot-Wielopolska, A. (2019). Żuławy i Powiśle: Kreowanie tożsamości lokalnych i regionalnych po 1989 roku. Warszawa: Wydawnictwo Naukowe Scholar.

Paradowska, M. (1998). Bambrzy. Mieszkańcy dawnych wsi miasta Poznania. Poznań: Media Rodzina.

Paradowska, M. (2001). Poznań Bambers - the Past and the Present. Ethnologia Polona, 22, 101-117.

Paradowska, M. (2002). Poznań. Zabytki bamberskie. Przewodnik. Poznań: Wydawnictwo Miejskie.

Paradowska, M. (2002). Bamberger Spuren: Stadtführer. Poznań: Wydawnictwo Miejskie.

Paradowska, M. (2003a). Współczesność Bambrów poznańskich. W: J. Kowalska, S. Szynkiewicz, R. Tomicki (red.). Czas zmiany, czas trwania. Studia etnologiczne (s. 223-232). Warszawa: Instytut Archeologii i Etnologii PAN. 
Rola liderów w kształtowaniu i promowaniu dziedzictwa...

Paradowska, M. (2003b). Bambrzy Poznańscy. Przeglad Zachodni, 1-2, 91-105.

Paradowska, M. (2003c). O historii Bambrów inaczej. Poznań: Wydawnictwo Miejskie.

Paradowska, M. (2004). The Museum of the Poznań Bambers and its socio-cultural significance. Ethnologia Polona, 25, 117-134.

Purchla, J. (2013). Dziedzictwo kulturowe. W: J. Hausner, J. Purchla, A. Karwińska (red.), Kultura a rozwój (s. 39-56). Warszawa: GAB.

Robertson, R. (1994). Globalisation or Glocalisation? The Journal of International Communication, 1(1), 33-52. DOI: doi.org/10.1080/13216597.1994 .9751780 .

Roigé, X., Frigolé, J. (2010). Introduction. W: X. Roigé, \& J. Frigolé (red.), Constructing cultural and natural heritage. Parks, museums and rural heritage (s. 9-24). Girona: ICRPC.

Saryusz-Wolska, M. (2009). Pamięć zbiorowa i kulturowa. Współczesna perspektywa niemiecka. Warszawa: Universitas.

Sobecka, A. (2014). Kalejdoskop. Spotkania z mniejszościami narodowymi. Gdańsk: Wydawnictwo Oskar.

Szacka, B. (2012). Historia, pamięć zbiorowa i connertonowska pamięć kulturowa. W: J. Adamowski, M. Wójcicka (red.), Tradycja dla wspótczesności. Pamięć jako kategoria rzeczywistości kulturowej (s. 13-20). Lublin: Wydawnictwo UMCS.

Szczepaniak-Kroll, A. (2002). The Problem of Emigration from Bamberg to Poland, Russia, and Hungary in the $18^{\text {th }}$ Century. Ethnologia Polona, 23, 85-112.

Szczepaniak-Kroll, A. (2004). The Role of the Bambers in the Economic and Cultural Life of Poznan in the $18^{\text {th }}$ Trough the $20^{\text {th }}$ Centuries. Ethnologia Polona, 25, 43-65.

Szczepaniak-Kroll, A. (2005). Problemy adaptacji Bambrów poznańskich w XVIII w., w świetle materiałów archiwalnych. Lud, 89, 205-225.

Szczepaniak-Kroll, A. (2010). Tożsamość poznańskich rodzin pochodzenia niemieckiego. Losy Bajerleinów i Dittrichów (XVIII-XX w.). Poznań: Wydawnictwo Poznańskie.

Szczepaniak-Kroll, A., Szymoszyn, A. (2019). Profesor Maria Paradowska i jej zasługi dla poznańskich Bambrów. Wspomnienia pracowników Instytutu Archeologii i Etnologii Polskiej Akademii Nauk w Poznaniu. W: M. Mrugalska-Banaszak (red.), Kronika Miasta Poznania. „Bambrzy” (s. 274288). Poznań: Wydawnictwo Miejskie Posnania.

Szymoszyn, A. (2019). Czy przybysze z Bambergu przywieźli ze sobą własnych świętych? W: M. Mrugalska-Banaszak (red.), Kronika Miasta Poznania. „Bambrzy” (s. 109-122). Poznań: Wydawnictwo Miejskie Posnania. 
Szpociński, A. (2008). Miejsca pamięci: lieux de memoire. Teksty Drugie: teoria literatury, krytyka, interpretacja, 4(112), 11-20.

Szwed, R. (2005). Tożsamość europejska versus tożsamość narodowa? Transformacja tożsamości zbiorowych w Unii Europejskiej. W: E. Hałas, K.T. Konecki (red.), Konstruowanie jaźni i społeczeństwa. Europejskie warianty interakcjonizmu symbolicznego (s. 310-344). Warszawa: Scholar.

Trzeciakowski, L. (1970). Kulturkampf w zaborze pruskim. Poznań: Wydawnictwo Poznańskie.

Walsh, K. (1992). The representation of the past. Museums and heritage in the post-modern world. London - New York: Routledge.

Zarządzanie... (2015). Zarządzanie światowym dziedzictwem kulturowym. Warszawa: Narodowy Instytut Dziedzictwa.

\section{ŹRÓDLA INTERNETOWE:}

Towarzystwo Bambrów Poznańskich, Statut, https://www.bambrzy.poznan.pl/ node/13 (dostęp: 15.04.2020 r.)

Paradowska, M. Towarzystwo Bambrów Poznańskich. Strona internetowa miasta Poznań, https://www.poznan.pl/mim/turystyka/-,p,4791,4795.html (dostęp: 15.04.2020 r.)

Paradowska, M. Święto bamberskie. Strona internetowa miasta Poznań, https:// www.poznan.pl/mim/turystyka/swieto-bamberskie,p,4791,4796.html, (dostęp: 20.04.2020 r.).

Poznańska Wiki, hasło: sztekiel, https://poznan.wikia.org/wiki/Sztekiel (dostęp: 14.05.2020 r.).

Bojarski, P. 20 lat temu mieliśmy szczyt weimarski w Poznaniu. Przyjechali na sandacza, prosię i piwo od Kulczyka. Gazeta Wyborcza 2018, http://poznan. wyborcza.pl/poznan/7,109268,23063201,20-lat-temu-mielismy-szczyt-weimarski-w-poznaniu-przyjechali.html (dostęp: 24.01.2019 r.).

Plenzler, A. Miasto spłaciło dług za budowę Muzeum Bambrów Poznańskich. Głos Wielkopolski, 28.10.2008, https:/gloswielkopolski.pl/miastosplacilo-dlug-za-budowe-muzeum-bambrow-poznanskich/ar/56229 (dostęp: 16.04.2020 r.).

Strona międzyszkolnego projektu lubońsko-bamberskiego, https://sp3lubon.pl/ projekt-lubon-bamberg-wspolna-przeszlosc-wspolna-przyszlosc/ (dostęp: 19.04.2020 r.).

Strona poznańskiego LO nr V i informacja o wymianie międzyszkolnej https://www.vlo.poznan.pl/page.php/1/1/show/000110/(dostęp: 19.04.2020 r.). 